\title{
Interchange Fees in Various Countries: Developments and Determinants
}

\author{
STUART E. WEINER * \\ Federal Reserve Bank of Kansas City \\ JULIAN WRIGHT \\ National University of Singapore
}

\begin{abstract}
Interchange fees and related issues in payment card markets have been the focus of considerable attention recently. The academic community and public officials have begun to scrutinize these markets. Meanwhile, these markets continue to experience dynamic change as card payments account for an ever-growing share of overall payments. This paper provides an overview of interchange fee developments and issues, and also presents a preliminary analysis of some possible contributing factors. The principal conclusion of the paper is that interchange arrangements vary considerably across countries, and while existing economic theory provides some insight into this market, much remains to be explained.
\end{abstract}

\section{Introduction}

Credit and debit cards have become a prominent form of payment throughout the world. The interchange fees associated with these payment instruments have, in some instances, seen considerable change in recent years. In some countries, interchange fees have experienced sharp movements following a period of relative stability. In other countries, they have remained relatively steady, but significant changes may be on the horizon. Behind many of these changes lie important, even landmark, industry developments and regulatory and central bank rulings.

A number of key issues and controversies currently surround credit and debit interchange fees. Most involve the rationale for and level of interchange fees. Typically paid by merchant acquirers to card issuers on a per-transaction basis, interchange fees in most countries are set by

\footnotetext{
* Contact author. Payments System Research Department, Federal Reserve Bank of Kansas City, 925 Grand Blvd., Kansas City, Missouri, USA, 64198, Email: stuart.e.weiner@kc.frb.org Paper originally prepared for "Interchange Fees in Credit and Debit Card Industries: What Role for Public Authorities?" Federal Reserve Bank of Kansas City International Payments Conference, Santa Fe, New Mexico, May 4-6, 2005. The authors wish to thank numerous colleagues for their comments and assistance, including Helen Allen, Ron Berndsen, Ann Borestam, Allan Damm Christensen, Alan Frankel, Bernhard Friess, Sergio Gorjon, Gabriela Guibourg, Nathan Halmrast, Fumiko Hayashi, Marc-Andre Lacombe, John Leaning, Carl Munson, Jose Luis Negrin, Paul Osse, Robin Prager, Johaness Priesemann, David Teal, Roland Uittenbogaard, and John Veale. The views expressed in this paper reflect those of the authors and do not necessarily reflect those of the institutions with which they are affiliated.
} 
credit and debit card networks. But in one country, Australia, the central bank is regulating interchange fees, and in several other countries and areas, including the UK, the European Union, the United States, the Netherlands, Mexico, and Spain, public officials and/or the courts are scrutinizing and debating interchange fees.

This paper provides an overview of interchange fees. It documents interchange fee developments in a number of countries and provides a preliminary analysis of possible contributing factors. The central message of the paper is that interchange arrangements vary considerably across countries, and while existing theory provides some insight into fee levels and movements, much remains to be explained. A number of complex and interrelated factors, many country-specific, play a role in interchange developments. To adequately test existing and future theories, richer data will be required.

The paper is organized as follows. The following section provides background on the function of interchange fees. It explains the idea of two-sided markets and how such markets are related to the fee structure of payments networks. Three-party and four-party payment schemes are discussed.

Section 3 of the paper provides an overview of interchange fee developments and issues in ten key countries and areas: Australia, Canada, Denmark, EU cross-border, Mexico, the Netherlands, Spain, Sweden, the UK, and the United States. Credit card, signature-based debit card, and PIN-based debit card markets are addressed separately. Among the topics covered: How do interchange fee arrangements vary across countries? How have interchange fees - and related fees such as a merchant discount fees and cardholder fees - moved in recent years? In which countries do various network rules, such as no-surcharge rules, honor-all-cards rules, netissuer rules, and duality rules, apply? Which countries have recently addressed or are currently addressing issues and controversies? In which countries have public authorities - competition authorities or central banks - played an active role in interchange fee discussions?

Section 4 of the paper explores possible determinants of the level of interchange fees. It first reviews some of the existing economic literature on interchange fees and highlights some general determinants implied by economic theory. Drawing on these insights, a preliminary examination of available empirical data is conducted to see whether there is any evidence pointing toward particular determinants. What emerges is a rejection of simple explanations. In practice, interchange fees are determined by a multitude of factors, so to properly explain them will require a multivariate approach and richer data sources. Finally, Section 5 offers closing remarks.

\section{Background}

If all cardholders and merchants obtained their card services from a single financial institution, there would be no need for an interchange fee. This is the case of a three-party (or proprietary) card scheme such as those traditionally offered by American Express or Diners Club. ${ }^{1}$ American Express, for instance, signs up cardholders and merchants, and deals directly with both groups. A central decision made by such a card scheme is how much to charge cardholders versus how much to charge merchants. If one considers only the payment services offered by a proprietary card scheme (excluding revenue from the extension of credit), such schemes typically obtain a

\footnotetext{
${ }^{1}$ American Express has increasingly been relying on issuing its card through banks, in which case it makes a payment to these banks for the cardholders (or card transactions) they generate, a payment akin to an interchange fee.
} 
majority of their revenue from merchants. They do this through merchant fees - fees that are obtained as a percentage of the value of each card transaction. For instance, American Express (2004) reports that it earned 71 percent of its card-related revenues from the merchant side of the business in 2004. In contrast, often cardholders pay no annual fees. Rather, cardholders are given an interest-free period over which to pay their outstanding balances, and rebates such as frequent flyer miles based on the value of their card transactions. Consumers who do not roll over credit card debt may therefore face a negative price for using credit cards. In the case of debit cards, on the other hand, consumers often pay per-transaction fees. ${ }^{2}$

These card schemes have to attract cardholders to get merchants and merchants to get cardholders. The choice of how much to charge cardholders versus merchants is an important aspect of attracting both types of users. Broadly speaking, card schemes will choose a structure of fees to the respective sides that drives overall transaction demand, and ultimately profit. Diners Club did this when it started up in 1950 by initially giving away cards to consumers and charging merchants $7 \%$ of their bill (Evans and Schmalensee, 2005a).

The issue of how much to charge each type of user is a common one in other two-sided markets. Magazines decide how much to charge readers versus advertisers, trading posts decide how much to charge buyers versus sellers, nightclubs decide how much to charge men versus women, expos decide how much to charge visitors versus exhibitors, and so on. In all these twosided markets, a platform seeks to attract the two sides to enable transactions between them, and has to make a decision about how much to charge each side. ${ }^{3}$ The situation with card systems is fundamentally the same one. This is obvious with a three-party scheme such as American Express since it makes its pricing decision directly. Less obviously, a similar situation arises for four-party schemes (card associations) such as MasterCard and Visa.

Consider the situation of a card association such as MasterCard or Visa, which offers a branded network over which its members (issuers and acquires) provide card services to endusers. Since it does not deal directly with consumers or merchants, the association does not get to directly determine the fees charged to each side. If each issuer and each acquirer sets its prices independently, the structure of prices across the two sides will then not be something that the association chooses directly. How then can the association determine a structure of prices as proprietary schemes or platforms on other two-sided markets do? The answer is by setting an interchange fee.

The interchange fee is an instrument that card associations can use to achieve a desired balance of cardholding (and usage) versus merchant acceptance across the two sides of the market, in the same way proprietary schemes or platforms in other two-sided markets can do directly. This provides a useful framework to think about the implications of interchange fees in which both sides of the market (both cardholders and merchants) are considered simultaneously. The framework contrasts with a vertically organized view of the industry, in which issuers sell services to acquirers, who then sell to merchants. This view misses the fact that issuers also service cardholders, and that the interaction of cardholders and merchants is essential to creating

\footnotetext{
${ }^{2}$ An exception is signature debit transactions in the United States, where consumers sometimes earn rebates.

${ }^{3}$ A recent literature has studied the economics of two-sided markets. See, for instance, Evans (2003a, 2003b), Rochet and Tirole (2004a, 2004b) and Wright (2004) for descriptions of a wide range of two-sided markets, and some discussion of the relevant literature and policy issues. See Armstrong (2004), Caillaud and Jullien (2003) and Rochet and Tirole (2003a) for general models of two-sided markets.
} 
a valuable service. The two-sided markets framework highlights the fact that the interchange fee is not a price for a single service, but instead acts as a balancing instrument. ${ }^{4}$

To see how interchange fees can play this role, consider a particular transaction between a consumer and a merchant using a MasterCard or Visa card. Typically, the consumer's card will be from a different bank than that which the merchant utilizes. Then the interchange fee is a payment made from the merchant's bank (the acquirer) to the consumer's bank (the issuer), usually, in the case of credit cards, as a percentage of the value of the transaction and, in the case of debit cards, often as a flat rate..$^{5}$ The level of this interchange fee is typically collectively set.

From the point of view of acquirers, the interchange fee is a cost of providing their services to merchants. An increase in the interchange fee will lead to an increase in acquirers' costs for every card transaction they process. Acquirers will therefore ultimately respond to an increase in the interchange fee by increasing their merchant fees. This is true regardless of whether there is a single acquirer or if there is strong competition among different acquirers, although the rate and timing of the pass-through of interchange fees to merchant fees can differ depending on the nature of acquirer competition. If pass-through is less than perfect, an increase in the interchange fee will cut into acquirers' profits, and may make acquirers less likely to promote the development of the particular card network.

Similarly, from the point of view of issuers, the interchange fee is a fee obtained for providing their services to cardholders (a payment that issuers receive). An increase in the interchange fee will mean an increase in the fee issuers receive for every card transaction their customers undertake. Issuers will therefore ultimately respond to an increase in the interchange fee by increasing benefits (for instance, rebates) to cardholders and/or decreasing their card fees, so as to encourage more card transactions. This is true regardless of whether there is a single issuer or if there is strong competition among different issuers, although the rate and timing of the pass-through of interchange fees to card fees can differ depending on the nature of issuer competition. If pass-through is less than perfect, an increase in the interchange fee will increase issuers' profits and may make issuers more likely to promote the development of the particular card network.

The net effect of an increase in a card association's interchange fee will therefore be to increase its acquirers' merchant fees and to decrease its issuers' card fees (or, equivalently, increase card benefits). With limited pass-through of interchange fees, the net effect may also be to decrease acquirers' profits and increase issuers' profits. In this case, it may also lead to more promotion of card services by issuers and less promotion of card services by acquirers. To the extent that the increase in merchant fees exactly equals the decrease in card fees, the interchange fee will change the structure of fees but not the overall level of the issuers' and acquirers' fees. To the extent that the increase in merchant fees does not match the decrease in card fees, changing the interchange fee will change the structure of fees and, at the same time, change the overall level of the issuers' and acquirers' fees.

In either case, the interchange fee is the key instrument the card association can use if it wants to achieve a particular structure of cardholder and merchant fees, or more generally, if it

\footnotetext{
${ }^{4}$ It is true, of course, that in some cases the interchange fee accounts for a large percentage of the merchant fee; for example, in the United States, roughly 75 percent, and in Sweden, 100 percent. In the latter case, the interchange fee will exactly match the price merchants pay for the acquiring service. However, since cardholder fees are inversely related to the interchange fee, this does not change the fact that the interchange fee determines the structure of prices to the two sides of the market

${ }^{5}$ Of course, there is nothing stopping the transfer being from issuers to acquirers, which implies a negative interchange fee is set. This is the case for Australian EFTPOS transactions.
} 
wants to expand one side of the market relative to the other. For instance, if the association and its members want to place more emphasis on expanding cardholding and usage relative to merchant acceptance, they will require a relatively high interchange fee. If the association and its members want to place more emphasis on expanding merchant acceptance relative to cardholding and usage, they will require a relatively low interchange fee. In this sense, the interchange fee is an instrument that card associations can use if they are to achieve a desired balance of cardholding (and usage) versus merchant acceptance across the two sides of the market, in the same way proprietary schemes or platforms in other two-sided markets can do directly. ${ }^{6}$

This is not to say that interchange fees cannot be used for other purposes. As was noted above, a higher interchange fee may also increase the overall level of fees, for instance, if acquirers pass through all of the additional cost of higher interchange fees but issuers keep a proportion of any increase in interchange fee revenue. ${ }^{7}$ If by so doing the card scheme can profitably raise the overall level of fees, the card scheme may profit at the expense of its customers (cardholders and merchants). Nor is it the case that card associations will necessarily set the "right" level of interchange fees from society's point of view, an issue taken up elsewhere (Evans and Schmalensee, 2005b; and Wright, 2004). The value of the two-sided markets approach is that it provides a logically consistent framework to analyze interchange fees that takes into account the demands of both sides of the market, and it can be used to explore these other issues as well. This framework will be used to analyze some possible determinants of interchange fees in Section 4.

Before doing so, however, the following section summarizes the interchange environment in several countries throughout the world.

\section{Developments and issues}

As noted in the preceding section, interchange fees are an integral part of the pricing structure of credit and debit card industries. This section documents interchange developments and issues across a number of countries. Countries include Australia, Canada, Denmark, EU cross-border, Mexico, the Netherlands, Spain, Sweden, the UK, and the United States. These countries share some common features but also exhibit many differences in how interchange and related fees and rules operate in their respective markets. In all of these countries, however, interchange fees currently are, to varying degrees, the focus of pointed industry and public-authority debate.

\footnotetext{
${ }^{6}$ Some authors have suggested interchange fees may not be able to be used in this way, since if merchants are charged more as a result of higher interchange fees, merchants will pass these costs on to cardholders, who will then be no better off even though they face lower card fees. See Gans and King (2003) for an analysis of the conditions under which interchange fees are neutral. Frankel (1998) noted that interchange fees would not be neutral even if merchants are allowed to surcharge in this way, due to what he called price coherence - the fact that most merchants will not want to discriminate their prices between card and non-card users for small differentials in costs.

${ }^{7}$ By the same logic, a higher interchange fee can also decrease the overall level of fees, when as a result issuers decrease their card fees more than acquirers increase their fees to merchants. Which situation arises in practice depends upon, among other things, the degree of competition amongst issuers versus amongst acquirers, as well as the degree of substitution between the different means of payment from the perspective from both types of users.
} 
One thing all of these countries share is the increasing importance of credit and debit cards in their overall payments system. ${ }^{8}$ All countries have experienced an increase in the share of credit and debit card transaction volume in recent years (Chart 1). In Canada, Denmark, and Sweden, in fact, credit and debit cards now account for more than half of all non-cash transactions. Debit card usage has grown particularly rapidly in many countries, with debit cards' share of overall
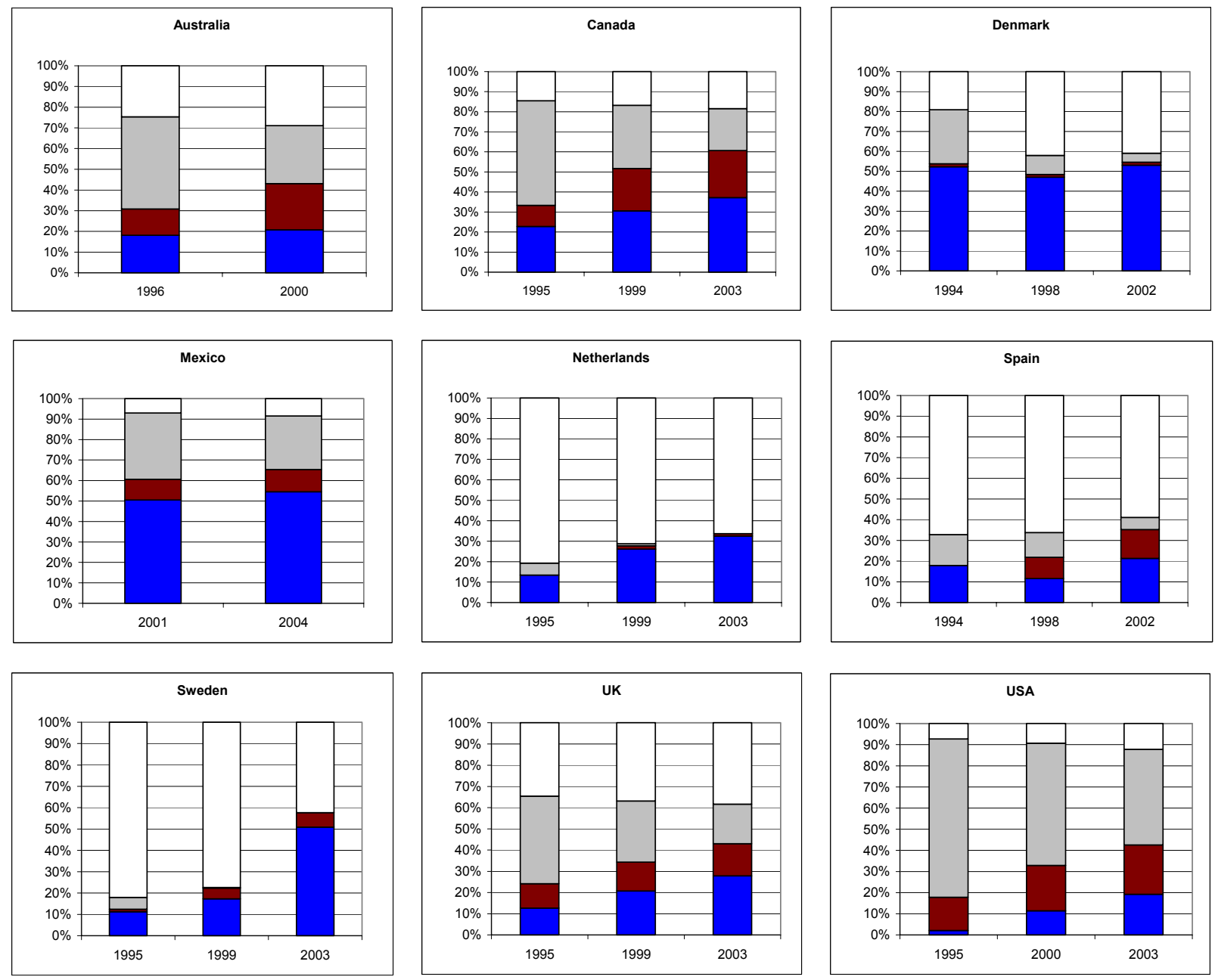

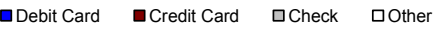

\section{Chart 1: Non-cash payment share (transaction volume)}

Note: Mexico debit card figures include ATM transactions.

Sources: BIS (1996-2005), ECB (2000, 2001, 2004), World Bank (2003), Euromonitor (2004), Federal Reserve System (2002, 2004), EMEAP (2002), Banco de Mexico.

\footnotetext{
${ }^{8}$ For institutional background on the payments card industry in various countries, see Bank for International Settlements (2003), European Central Bank (2001), Evans and Schmalensee (2005a), and Hayashi, Sullivan, and Weiner (2003).
} 
noncash transactions doubling, tripling, or even more in the Netherlands, the UK, and the United States in just a few years. This pronounced growth in credit and debit card usage has undoubtedly come at the expense, at least in part, of the paper check, which has declined steadily in all countries. Debit card usage, in particular, has probably also substituted for cash, although cash usage is very difficult to measure and is not included in the above share statistics.

The section is organized as follows. The first three subsections discuss developments and issues in the credit, signature-based debit, and PIN-based debit card markets separately. The discussion is guided by information presented in Tables 1, 2, and 3, respectively. In these tables, the ten individual countries and areas are listed as rows and for each, key interchange-related information is provided in the columns: instrument market share (column 3); networks operating in that country (column 4); what bodies set interchange fees for those networks (column 5); recent movements in interchange fees (column 6); recent movements in merchant service charges (column 7); recent movements in cardholder fees (column 8); whether no-surcharge (column 9), honor-all-cards (column 10), net-issuer (column 11), and duality/exclusion rules (column 12) are in force in various networks; and finally, interchange-related issues and controversies recently or currently under debate (column 13). The closing subsection delves more deeply into publicauthority involvement in interchange discussions, documenting, with the aid of Table 4, actions and rulings taken by or pending before competition authorities and central banks in these ten countries.

\subsection{Credit cards}

Credit cards are an important payment instrument in many of the countries under review. ${ }^{9}$ As noted in column 3 of Table 1, they are most prominent, in terms of share of overall noncash transactions volume, in Canada, the United States, Australia, the UK, and Spain. ${ }^{10}$ Column 4 shows the credit card networks operating in the ten countries and areas. Four-party networks are listed above the dotted line while three-party networks are listed below the dotted line. Networks with an asterisk behind them are networks available for international use only, that is, networks that issue cards to that country's residents for international use and are available for foreigner's use within the country. Another convention followed in Tables 1 through 3 relates to missing information. When a statement or attribute is not attached to a specific network, it can be taken to hold for all networks in that country. When a statement or attribute is attached to a specific network, it applies only to that network, and comparable information not shown for other networks means that such information is not available. Finally, in the tables, "nap" denotes not applicable, and "neg" denotes negligible.

Interchange fees are set under a variety of arrangements (column 5). In some countries they are collectively set by members of the network, sometimes subject to regulatory limits; in others they are set by network management; in one country, Mexico, they are set by members of the Mexican Bankers Association; and in another, Sweden, they are set bilaterally. In Demark, interchange fees are aligned with merchant service charges, which are subject to a regulatory cap. $^{11}$

In most countries interchange fees have declined or are declining (column 6). In some countries, this is due to recent regulation or regulatory threat: Australia, Mexico, and EU crossborder. In Spain, interchange fees have been declining as a result of a 1999 agreement among

\footnotetext{
9 "Credit cards" includes charge cards as well as deferred debit transactions

${ }^{10}$ In Spain, charge card transactions are predominant.

${ }^{11}$ In addition, in many countries, MasterCard members are permitted to negotiate interchange fees bilaterally.
} 


\begin{tabular}{|c|c|c|c|c|c|c|c|}
\hline & & Marke & aformation & Interchange Fees & & Other Fees & \\
\hline Region & Country & Share & Networks & Set by Whom & $\begin{array}{l}\text { Recent } \\
\text { Movements }\end{array}$ & $\begin{array}{l}\text { Recent MSC } \\
\text { Movements }\end{array}$ & $\begin{array}{l}\text { Recent Cardholder } \\
\text { Fee Movements }\end{array}$ \\
\hline 1 & 2 & 3 & 4 & 5 & 6 & \begin{tabular}{|l|}
7 \\
\end{tabular} & 8 \\
\hline $\begin{array}{l}\text { Asia } \\
\text { Pacific }\end{array}$ & Australia & $22 \%$ & $\begin{array}{l}\text { Bankcard } \\
\text { MC,Visa } \\
\text { Amex, } \\
\text { Diners, } \\
\text { JCB }\end{array}$ & $\begin{array}{l}\text { Bankcard/MC/Visa: } \\
\text { collectively set by } \\
\text { members of the } \\
\text { networks subject to } \\
\text { regulatory limits }\end{array}$ & Declined & Declined & $\begin{array}{l}\text { Annual Fees: } \\
\text { Increasing } \\
\text { Interest-Free Period: } \\
\text { Declining } \\
\text { Rewards: Declining } \\
\end{array}$ \\
\hline \multirow{5}{*}{$\begin{array}{l}\text { North } \\
\text { America }\end{array}$} & \multirow[b]{2}{*}{ Canada } & \multirow[b]{2}{*}{$23 \%$} & MC, Visa & \multirow{2}{*}{$\begin{array}{l}\text { MC/Visa: collectively } \\
\text { set by members of the } \\
\text { networks }\end{array}$} & \multirow{2}{*}{$\begin{array}{l}\text { MC: } \\
\text { Increased }\end{array}$} & \multirow{2}{*}{$\begin{array}{l}\text { MC: } \\
\text { Increased }\end{array}$} & \\
\hline & & & $\begin{array}{l}\text { Amex, } \\
\text { Diners }\end{array}$ & & & & \\
\hline & Mexico & $10 \%$ & MC, Visa & $\begin{array}{l}\text { MC/Visa: collectively } \\
\text { set by members of the } \\
\text { Mexican Bankers' } \\
\text { Association (MC and } \\
\text { Visa have the same } \\
\text { rates) }\end{array}$ & Declining & & \\
\hline & \multirow[b]{2}{*}{ USA } & \multirow[b]{2}{*}{$23 \%$} & MC, Visa & \multirow{2}{*}{$\begin{array}{l}\text { MC: set by } \\
\text { management } \\
\text { Visa: collectively set } \\
\text { by members of the } \\
\text { network }\end{array}$} & \multirow[b]{2}{*}{ Increasing } & \multirow[b]{2}{*}{ Increasing } & \multirow{2}{*}{$\begin{array}{l}\text { Annual Fees: } \\
\text { Declining Interest } \\
\text { Rates: Zero } \\
\text { introductory interest } \\
\text { rates prevalent } \\
\text { Rewards: Increasing } \\
\end{array}$} \\
\hline & & & $\begin{array}{l}\text { Amex, } \\
\text { Diners } \\
\text { Discover, } \\
\text { JCB }\end{array}$ & & & & \\
\hline \multirow{6}{*}{ Europe } & $\begin{array}{l}\text { EU cross- } \\
\text { border }\end{array}$ & nap & MC, Visa & $\begin{array}{l}\text { MC: collectively set by } \\
\text { members of the } \\
\text { network } \\
\text { Visa: collectively set } \\
\text { by members of the } \\
\text { network subject to } \\
\text { regulatory agreement }\end{array}$ & Declining & nap & nap \\
\hline & Denmark & $1 \%$ & $\begin{array}{l}\text { MC, Visa* } \\
\text { Amex, } \\
\text { Diners }\end{array}$ & $\begin{array}{l}\text { MC/Visa: aligned with } \\
\text { MSCs, which are } \\
\text { subject to regulatory } \\
\text { cap }\end{array}$ & Stable & Stable & \\
\hline & $\begin{array}{l}\text { Nether- } \\
\text { lands }\end{array}$ & $1 \%$ & $\begin{array}{l}\text { MC, Visa } \\
\text { Amex, } \\
\text { Diners, } \\
\text { JCB }\end{array}$ & $\begin{array}{l}\text { MC: collectively set by } \\
\text { members of the } \\
\text { network }\end{array}$ & Declining & Declining & \\
\hline & Spain & $14 \%$ & $\begin{array}{l}\text { MC, Visa } \\
\text { Amex, } \\
\text { Diners, } \\
\text { JCB }\end{array}$ & & Declining & Declining & $\begin{array}{l}\text { Annual Fees: } \\
\text { Increasing }\end{array}$ \\
\hline & Sweden & $7 \%$ & $\begin{array}{l}\text { MC, Visa } \\
\text { Amex, } \\
\text { Diners }\end{array}$ & $\begin{array}{l}\text { MC/Visa: negotiated } \\
\text { bilaterally }\end{array}$ & Declining & & \\
\hline & UK & $15 \%$ & $\begin{array}{l}\text { MC, Visa } \\
\text { Amex, } \\
\text { Diners, } \\
\text { JCB }\end{array}$ & $\begin{array}{l}\text { MC: set by } \\
\text { management } \\
\text { Visa: collectively set } \\
\text { by members of the } \\
\text { network }\end{array}$ & Declining & Stable & $\begin{array}{l}\text { Annual Fees: Zero } \\
\text { fees prevalent } \\
\text { Interest Rates: Zero } \\
\text { introductory interest } \\
\text { rates prevalent } \\
\text { Rewards: Available }\end{array}$ \\
\hline
\end{tabular}

\section{Table 1: Credit card}

Notes: 1. In column (4), four-party networks are listed above the line while three-party networks are listed below; “*” denotes networks that issue cards to that country's residents for international use and are available for foreigner's use within the country. 2. "nap" denotes not applicable 


\begin{tabular}{|c|c|c|c|c|c|c|}
\hline \multirow[b]{2}{*}{ Region } & \multirow[b]{2}{*}{ Country } & \multicolumn{4}{|c|}{ Network Rules } & \multirow[b]{2}{*}{ Issues } \\
\hline & & $\begin{array}{l}\text { No - } \\
\text { Surcharge }\end{array}$ & $\mathrm{HAC}$ & Net Issuer & $\begin{array}{l}\text { Duality / } \\
\text { Exclusion }\end{array}$ & \\
\hline 1 & 2 & 9 & 10 & 11 & 12 & 13 \\
\hline \multirow{2}{*}{$\begin{array}{l}\text { Asia } \\
\text { Pacific }\end{array}$} & \multirow{2}{*}{ Australia } & \multirow{2}{*}{$\begin{array}{l}\text { Bankcard: } \\
\text { No } \\
\text { MC: No } \\
\text { Visa: No }\end{array}$} & \multirow{2}{*}{ Yes } & \multirow{2}{*}{$\begin{array}{l}\text { Bankcard: } \\
\text { Yes } \\
\text { MC: Yes } \\
\text { Visa: Yes }\end{array}$} & \multirow{2}{*}{ Yes/No } & $\begin{array}{l}\text { 1. Reserve Bank of Australia regulations lowering credit } \\
\text { card interchange fees and eliminating credit card no- } \\
\text { surcharge rules. }\end{array}$ \\
\hline & & & & & & $\begin{array}{l}\text { 2. In light of regulation of four-party schemes, potential } \\
\text { shift in transactions volume to nonregulated three-party } \\
\text { schemes. }\end{array}$ \\
\hline \multirow{8}{*}{$\begin{array}{l}\text { North } \\
\text { America }\end{array}$} & Canada & $\begin{array}{l}\text { MC/Visa: } \\
\text { Yes }\end{array}$ & nap & MC: Yes & $\mathrm{No} /$ & "Synthetic duality" for MC and Visa. \\
\hline & \multirow{3}{*}{ Mexico } & \multirow{3}{*}{$\begin{array}{l}\text { MC/Visa: } \\
\text { Yes }\end{array}$} & \multirow{3}{*}{ Yes } & \multirow{3}{*}{ MC: Yes } & \multirow{3}{*}{ Yes/ } & $\begin{array}{l}\text { 1. Interchange fees have been reduced due to a } \\
\text { concerted effort between Banco de Mexico and the } \\
\text { Mexican Bankers Association. }\end{array}$ \\
\hline & & & & & & $\begin{array}{l}\text { 2. Banco de Mexico has made the HAC rule more } \\
\text { flexible: merchants are allowed to accept only debit, } \\
\text { credit, or both cards. }\end{array}$ \\
\hline & & & & & & $\begin{array}{l}\text { 3. The no-surcharge rule was left intact because } \\
\text { discounts are already allowed. }\end{array}$ \\
\hline & \multirow{4}{*}{ USA } & \multirow{4}{*}{$\begin{array}{l}\text { MC/Visa: } \\
\text { Yes }\end{array}$} & \multirow{4}{*}{ No } & \multirow{4}{*}{ MC: No } & \multirow{4}{*}{ Yes/No } & 1. Wal-Mart HAC case. \\
\hline & & & & & & 2. Merchant dissatisfaction with interchange fee levels. \\
\hline & & & & & & $\begin{array}{l}\text { 3. DOJ-led court case eliminating MC and Visa } \\
\text { exclusion rules that prohibited member banks from } \\
\text { issuing American Express and Discover credit cards. }\end{array}$ \\
\hline & & & & & & 4. Appearance of volume-based interchange fee tiers. \\
\hline \multirow{12}{*}{ Europe } & \multirow{5}{*}{$\begin{array}{l}\text { EU cross- } \\
\text { border }\end{array}$} & \multirow{5}{*}{ Visa: Yes } & & \multirow{5}{*}{ Visa: Yes } & \multirow{5}{*}{ Visa: /Yes } & $\begin{array}{l}\text { 1. Visa agreement to reduce cross-border interchange } \\
\text { fees. }\end{array}$ \\
\hline & & & & & & $\begin{array}{l}\text { 2. Visa's no-surcharge and net issuer rules left intact by } \\
\text { EC. }\end{array}$ \\
\hline & & & & & & 3. MasterCard's interchange fees under EC review. \\
\hline & & & & & & $\begin{array}{l}\text { 4. Exclusion provisions in Visa's membership rules } \\
\text { under EC review. }\end{array}$ \\
\hline & & & & & & 5. MC eliminated its no-surcharge rule. \\
\hline & Denmark & & nap & MC: No & Yes/No & Debate over surcharging. \\
\hline & $\begin{array}{l}\text { Nether- } \\
\text { lands }\end{array}$ & No & nap & MC: No & Yes/ & \\
\hline & \multirow[t]{2}{*}{ Spain } & \multirow[t]{2}{*}{ Visa: Yes } & & \multirow[t]{2}{*}{ MC: No } & \multirow[t]{2}{*}{ Yes/No } & $\begin{array}{l}\text { 1. Agreements among banks, networks, merchants, and } \\
\text { government agencies have led to reduction in } \\
\text { interchange fees since } 1999 \text {. A further lowering of fees } \\
\text { may result from an April } 2005 \text { ruling by the Tribunal de } \\
\text { Defensa de la Competencia. }\end{array}$ \\
\hline & & & & & & $\begin{array}{l}\text { 2. There is some dissatisfaction with lack of } \\
\text { transparency in fee setting. }\end{array}$ \\
\hline & Sweden & Visa: Yes & & MC: No & Yes/No & \\
\hline & \multirow[t]{2}{*}{ UK } & \multirow[t]{2}{*}{ No } & & \multirow{2}{*}{$\begin{array}{l}\text { MC/Visa: } \\
\text { Yes }\end{array}$} & Yes/ & $\begin{array}{l}\text { 1. OFT has ruled that the } 2000-2004 \mathrm{MC} \text { multilateral } \\
\text { interchange fee agreements were anti-competitive and is } \\
\text { now investigating MC's current arrangements. }\end{array}$ \\
\hline & & & & & & $\begin{array}{l}\text { 2. OFT has issued a statement of objections against } \\
\text { Visa's domestic multilateral interchange fee agreement. }\end{array}$ \\
\hline
\end{tabular}

Table 1: Credit card (cont.) 
banks, networks, merchants, and the Ministry of the Economy. ${ }^{12}$ A notable outlier is the United States, where interchange fees on credit cards have been rising in recent years. In fact, as shown in Chart 2, interchange fees in the United States are more than double those in some other countries (Australia, EU cross-border, and the UK). Indeed, U.S. fees were significantly higher even before the fees in these other countries were forced down by actual or anticipated regulation.

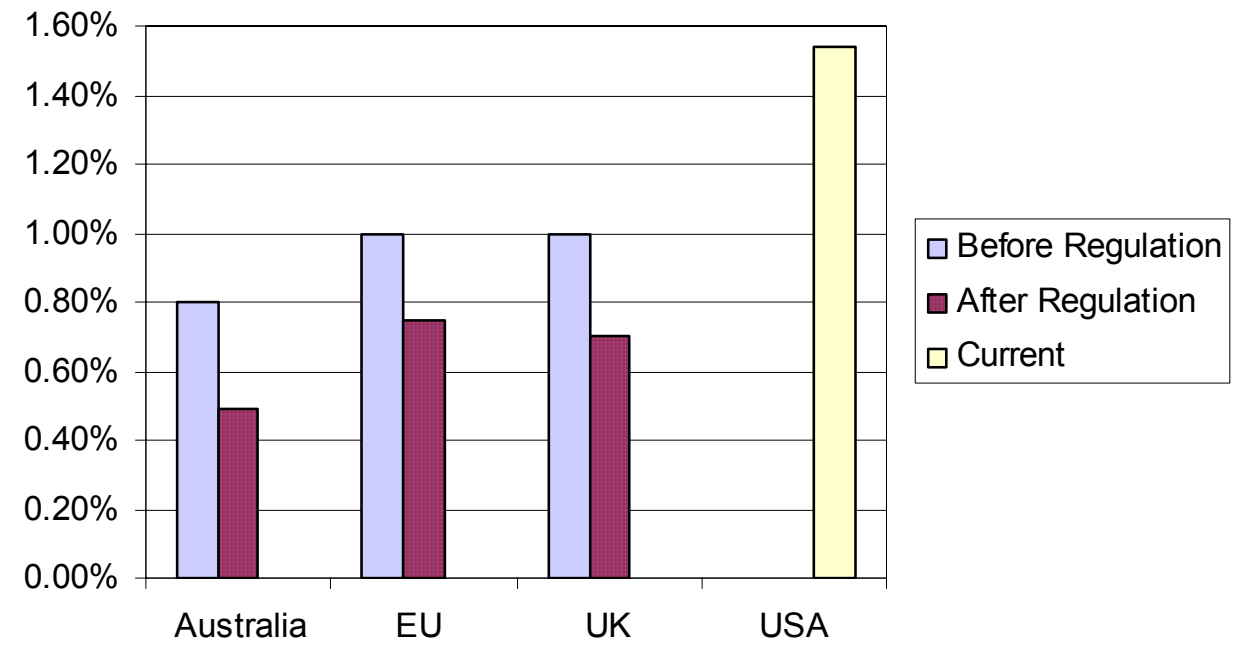

\section{Chart 2: Credit card interchange fees in selected countries}

Notes: From Hayashi (2004), "A Puzzle of Card Payment Pricing: Why Are Merchants Still Accepting Card Payments?" Federal Reserve Bank of Kansas City Payments System Research WP04-02, p.3. UK figures are estimates. 'Before' = before the rate was forced to be lowered; 'After' = after the rate was lowered; 'Current' $=$ as of November, 2004. In Australia, the regulation is effective for both Visa and MasterCard. The 'before' and 'after' rates are the average of Visa and MasterCard electronic rates. In the EU, the European Commission made its decision on the Visa rate for cross-border transactions only. The 'before' rate is not publicly available, but the average rate was estimated at about 1 percent according to the report "Credit Card Services" by the UK Monopolies and Mergers Commission and others. The 'after' rate is Visa's electronic authorization rate. In the UK, the antitrust authority has not made a final decision on credit card interchange rates. Therefore, the 'after' rate is an expectation by industry observers. They predict the regulated interchange rate will be between 0.35 to 0.7 percent. See, for example, The Times, May 17, 2004 and November 11, 2004, and Financial Times, November 11, 2004. The U.S. rate is the average of Visa and MasterCard default rates for retail stores.

Sources: Reserve Bank of Australia, Visa Europe, MasterCard International, American Banker.

Although difficult to document, merchant service charge movements appear to have tracked interchange fee movements to some extent (column 7). Cardholder fee movements have also tended to move in the expected direction (column 8). In countries where interchange fees have declined, for example, Australia and Spain, annual fees have increased and, in the case of Australia, interest-free periods have shortened and rewards programs have become less generous. In the United States, where interchange fees have risen, annual fees have declined, reward programs have become more generous, and zero introductory interest rates have become

\footnotetext{
${ }^{12}$ A further lowering of fees may result from an April 2005 ruling by the Tribunal de Defensa de la Competencia.
} 
prevalent. Here the UK appears to be something of an outlier, with interchange fees falling but annual-fee and introductory-rate provisions remaining relatively generous.

The ten countries/areas exhibit considerable variation across the principal categories of network rules: no-surcharge rules, honor-all-cards (HAC) rules, net issuer rules, and duality/exclusion rules. No-surcharge rules prevent merchants from charging customers for the use of a particular payment mechanism, in this case, a credit card. Honor-all-card rules, as defined here, require merchants that accept a network's credit card to also accept that network's signature-based debit card, if the latter exists in a given country. ${ }^{13}$ Net issuer rules require acquiring banks to issue a minimum level of cards in order to participate on the acquiring side of the market. Duality rules allow a bank that issues MasterCard credit cards to also issue Visa credit cards. Finally, exclusion rules prevent a bank that issues MasterCard or Visa credit cards from issuing other credit cards, for example, American Express and Discover.

No-surcharge rules are presently in effect in Canada, Mexico, the United States, and Sweden (column 9). They also are in effect - for Visa - for EU cross-border and Spanish transactions. On the other hand, surcharging is permitted in Australia, the Netherlands, and the UK and, for MasterCard, also in Spain and EU cross-border. ${ }^{14}$

Honor-all-card rules have a particularly interesting history in the United States (column 10). The so-called Wal-Mart case, brought by several merchants and trade associations against Visa and MasterCard in the mid-1990s and finally settled in 2003, eliminated Visa and MasterCard HAC rules. Net issuer rules are in place in roughly half of the countries under review (column 11). Duality is allowed in all countries but Canada; exclusion rules vary (column 12).

Turning to the last column of Table 1, industry participants and public authorities in virtually all of the countries have dealt with or are currently discussing issues and controversies surrounding credit card interchange fees and related matters. These range from regulations or agreements lowering interchange fees (Australia, Mexico, EU cross-border) or capping merchant service charges (Denmark), to regulations eliminating or permitting no-surcharge rules (Australia, EU cross-border), to merchant dissatisfaction with interchange levels (United States, Spain, EU cross border, UK), to complaints or concerns over three-party network schemes (Australia, United States), transparency (Spain, EU cross border, Australia), and duality (Canada). Thus, there is no shortage of challenging issues confronting the industry.

\subsection{Signature-based debit cards}

Table 2 presents information on signature-based debit cards. Signature-based cards have an important presence in a few countries, for example, the United States and Spain, and in other countries, Canada, Denmark, and the Netherlands, they are essentially nonexistent (column 3). As the name suggests, they are debit cards that require a signature, not a PIN, for authorization. MasterCard and Visa signature debit transactions run over MasterCard's and Visa's respective credit card networks. The three Spanish signature debit card networks, Euro 6000, ServiRed, and Sistema $4 \mathrm{~B}$, are stand-alone proprietary systems. ${ }^{15}$

\footnotetext{
${ }^{13}$ In Europe, the term "honor-all-cards rule" is typically defined differently, namely, if a merchant accepts a MasterCard \Visa-branded credit card issued by Bank A, the merchant must also accept a MasterCard $\backslash$ Visa-branded credit card issued by Bank B and, similarly, if a merchant accepts a MasterCard $\backslash$ Visa-branded PIN debit card issued by Bank A, the merchant must also accept a MasterCard/Visa-branded PIN debit card issued by Bank B. Thus, in Europe, honor-all-cards rules typically do not tie debit cards to credit cards.

${ }^{14}$ Although MasterCard allows surcharging in Spain, the three domestic card networks do not.

15 These networks also process MasterCard and Visa credit card and debit card transactions.
} 


\begin{tabular}{|c|c|c|c|c|c|c|c|}
\hline & & $\begin{array}{l}\text { Marke } \\
\text { Inform }\end{array}$ & tion & Interchange Fees & & Other Fees & \\
\hline Region & Country & Share & Networks & Set by Whom & $\begin{array}{l}\text { Recent } \\
\text { Movements }\end{array}$ & $\begin{array}{l}\text { Recent MSC } \\
\text { Movements }\end{array}$ & $\begin{array}{l}\text { Recent } \\
\text { Cardholder Fee } \\
\text { Movements }\end{array}$ \\
\hline 1 & 2 & 3 & 4 & 5 & 6 & 7 & 8 \\
\hline $\begin{array}{l}\text { Asia } \\
\text { Pacific }\end{array}$ & Australia & $21 \%+$ & Visa & $\begin{array}{l}\text { Visa: collectively set by } \\
\text { members of the network }\end{array}$ & Declined & Declined & \\
\hline \multirow{18}{*}{$\begin{array}{l}\text { North } \\
\text { America }\end{array}$} & Canada & neg & nap & nap & nap & nap & nap \\
\hline & \multirow[b]{2}{*}{ Mexico } & \multirow[b]{2}{*}{$51 \% \#$} & $\mathrm{MC}$ & MC/Visa: collectively set by & \multirow[b]{2}{*}{ Declining } & & \\
\hline & & & Visa & $\begin{array}{l}\text { members of the Mexican } \\
\text { Bankers' Association (MC } \\
\text { and Visa have the same rates) }\end{array}$ & & & \\
\hline & \multirow[b]{2}{*}{ USA } & \multirow[b]{2}{*}{$13 \%$} & $\mathrm{MC}$ & MC: set by management & \multirow[b]{2}{*}{ Net decline } & \multirow[b]{2}{*}{ Net decline } & \\
\hline & & & Visa & $\begin{array}{l}\text { Visa: collectively set by } \\
\text { members of the network }\end{array}$ & & & \\
\hline & \multirow[b]{2}{*}{$\begin{array}{l}\text { EU cross- } \\
\text { border }\end{array}$} & \multirow[b]{2}{*}{ nap } & $\mathrm{MC}$ & $\begin{array}{l}\text { MC: collectively set by } \\
\text { members of the network }\end{array}$ & \multirow[b]{2}{*}{ Declining } & \multirow[b]{2}{*}{ nap } & \multirow[b]{2}{*}{ nap } \\
\hline & & & Visa & $\begin{array}{l}\text { Visa: collectively set by } \\
\text { members of the network } \\
\text { subject to regulatory } \\
\text { agreement }\end{array}$ & & & \\
\hline & Denmark & neg & nap & nap & nap & nap & nap \\
\hline & $\begin{array}{l}\text { Nether- } \\
\text { lands }\end{array}$ & neg & nap & nap & nap & nap & nap \\
\hline & \multirow{5}{*}{ Spain } & \multirow{5}{*}{$21 \%$} & Euro 6000 & \multirow{5}{*}{$\begin{array}{l}\text { Euro6000/ServiRed/Sistema4 } \\
\text { B:set their own levels subject } \\
\text { to regulatory agreement }\end{array}$} & \multirow{5}{*}{ Declining } & \multirow{5}{*}{ Declining } & \\
\hline & & & $\mathrm{MC}^{*}$ & & & & \\
\hline & & & ServiRed & & & & \\
\hline & & & $\begin{array}{l}\text { Sistema } \\
\text { 4B }\end{array}$ & & & & \\
\hline & & & Visa* & & & & \\
\hline & \multirow{2}{*}{ Sweden } & \multirow{2}{*}{$51 \%+$} & $\mathrm{MC}$ & \multirow{2}{*}{$\begin{array}{l}\text { MC/Visa: negotiated } \\
\text { bilaterally }\end{array}$} & & & \\
\hline & & & Visa & & & & \\
\hline & \multirow{2}{*}{ UK } & \multirow{2}{*}{$28 \%+$} & $\mathrm{MC}$ & MC: set by S2 Card Services & & \multirow{2}{*}{ Stable } & \\
\hline & & & Visa & $\begin{array}{l}\text { Visa: collectively set by } \\
\text { members of the network }\end{array}$ & & & \\
\hline
\end{tabular}

Table 2: Signature-based debit card

Notes: 1. "*” denotes networks that issue cards to that country's residents for international use and are available for foreigner's use within the country. 2. "+" indicates share includes PIN-based transactions. 3. "\#” denotes share includes ATM transactions. 4. "nap" denotes not applicable. 5. "neg” denotes negligible. 


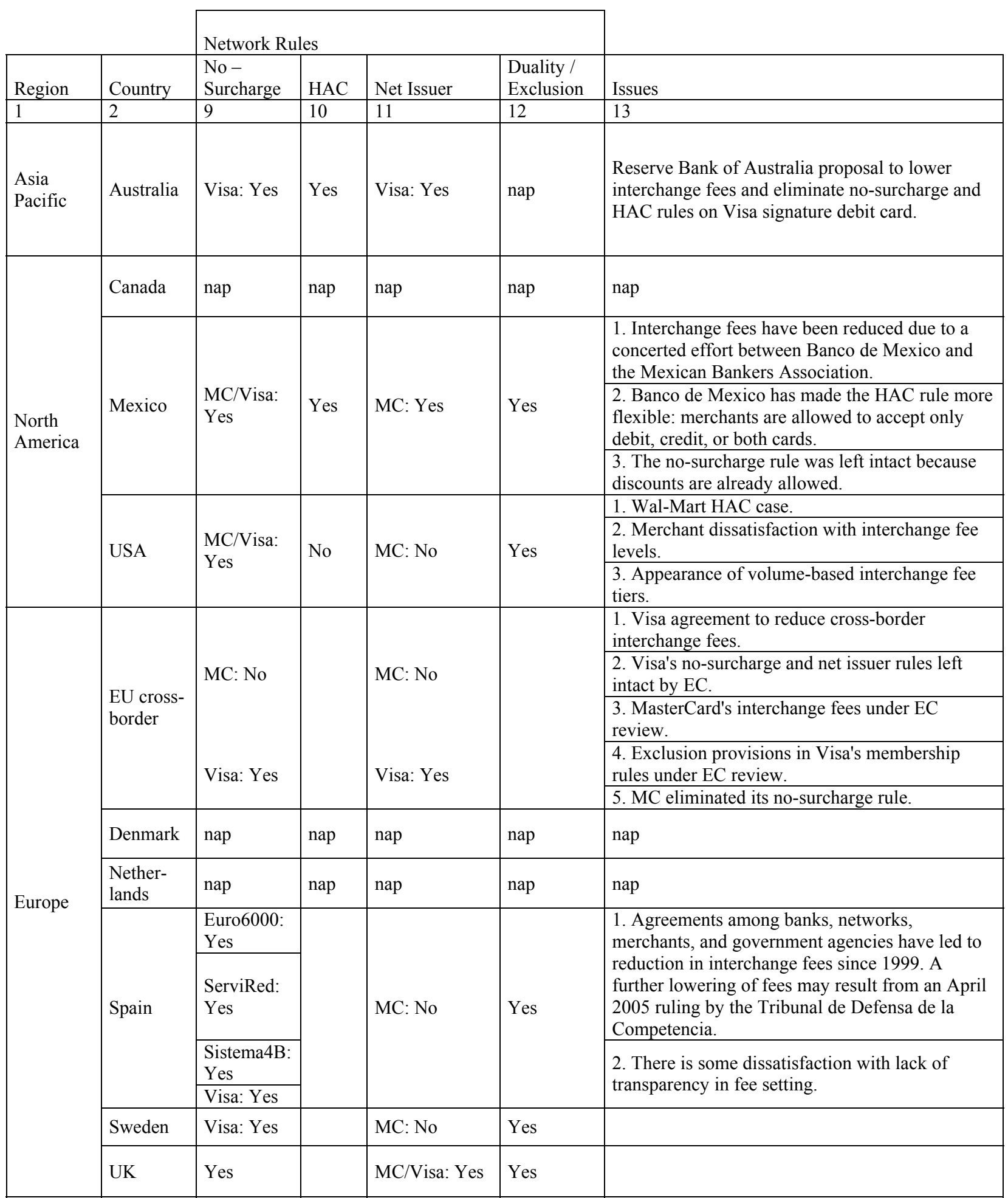

Table 2: Signature-based debit card (cont.)

In this subsection and the next, to keep things a little simpler, the general terms "MasterCard" and "Visa" are used to denote the various MasterCard and Visa signature and PINbased debit products. Thus, Visa CheckCard (United States signature), Visa Debit (Australian signature), Visa Electron (European PIN), and Visa Interlink (United States PIN) are all referred 
to as Visa, while MasterCard MasterMoney (United States signature) and MasterCard Maestro (worldwide PIN) are all referred to as MasterCard.

As is the case with credit cards, interchange fees on signature debit have tended to decline in recent years (column 6), often attributable to regulatory action (EU cross border), regulatory threat (Mexico), or government-led industry agreement (Spain). Interchange fees on U.S. signature debit, in contrast, have taken a different route. As part of the Wal-Mart settlement, they were reduced by roughly a third over the period August to December 2003, but since that time they have risen to some extent. ${ }^{16}$ Merchant service charges appear, for the most part, to have moved in the same direction as interchange fees, although, like cardholder fee movements, complete data are hard to obtain (columns 7,8).

Typically, signature-based debit transactions are subject to the same no-surcharge rules as credit cards in the various countries, and by definition, all honor-all-cards rules are also the same (columns 9, 10). Net issuer and duality rules also coincide (columns 11, 12).

A number of signature debit issues are currently under discussion (column 13). In Australia, the Reserve Bank of Australia has proposed lowering interchange fees and eliminating the nosurcharge and HAC rules on the Visa signature card. In the United States, there is widespread merchant dissatisfaction with the level of interchange fees, and in Spain some merchants reportedly believe merchant service charges remain too high. The EC, meanwhile, has MasterCard's fee policy under review, having reached an earlier agreement with Visa for Visa to lower its cross-border fees.

\subsection{PIN-based debit cards}

Table 3 presents information on PIN-based debit cards. PIN-based cards have a large presence in many European countries as well as in Canada, Australia, and the United States (column 4). MasterCard and Visa operate PIN-based systems in several of these countries; in addition, domestic systems are especially prominent in Australia, Canada, the United States, Denmark, and the Netherlands (column 4). ${ }^{17}$

PIN-based networks display a variety of institutional features and practices across countries. In Australia, for example, EFTPOS PIN debit interchange fees are set bilaterally and, notably, are paid by the issuer to the acquirer. In Canada and the Netherlands, interchange fees are set at zero by Interac and Interpay, respectively. Swedish PIN interchange fees are negotiated bilaterally. And in the United States, PIN interchange fees are often a competitive tool for attracting issuers - the United States is characterized by a large number of good-sized domestic networks, the largest of which (Star, NYCE, and Pulse) compete vigorously with Visa (columns $4,5)$.

Interchange fee movements have shown varying patterns in recent years (column 6). They have remained at zero in Canada and the Netherlands and have been stable in Australia. In Denmark, MasterCard and Visa fees have declined, while positive fees for Dankort transactions

\footnotetext{
${ }^{16}$ After rising in 2004, some signature interchange fees were lowered in April 2005. Most remain above postsettlement levels, however.

${ }^{17}$ In many cases, MasterCard and Visa PIN debit cards are co-branded with domestic schemes, and routing priority is given to the latter.
} 


\begin{tabular}{|c|c|c|c|c|c|c|c|}
\hline & & Market & aformation & Interchange Fees & & Other Fees & \\
\hline Region & Country & Share & Networks & Set by Whom & $\begin{array}{l}\text { Recent } \\
\text { Movements }\end{array}$ & $\begin{array}{l}\text { Recent MSC } \\
\text { Movements }\end{array}$ & $\begin{array}{l}\text { Recent } \\
\text { Cardholder Fee } \\
\text { Movements }\end{array}$ \\
\hline 1 & 2 & 3 & 4 & 5 & 6 & 7 & 8 \\
\hline $\begin{array}{l}\text { Asia } \\
\text { Pacific }\end{array}$ & Australia & $21 \%+$ & $\begin{array}{l}\text { EFTPOS } \\
\text { MC* } \\
\text { Visa* } \\
\end{array}$ & $\begin{array}{l}\text { EFTPOS: bilaterally set; } \\
\text { paid by issuer to acquirer }\end{array}$ & $\begin{array}{l}\text { EFTPOS: } \\
\text { Stable }\end{array}$ & & $\begin{array}{l}\text { Per-transaction } \\
\text { fees typical }\end{array}$ \\
\hline & Canada & $36 \%$ & $\begin{array}{l}\text { Interac } \\
\mathrm{MC}^{*}\end{array}$ & Interac: sets it at zero & Interac: Zero & & $\begin{array}{l}\text { Per-transaction } \\
\text { fees typical }\end{array}$ \\
\hline & Mexico & nap & nap & nap & nap & nap & nap \\
\hline $\begin{array}{l}\text { North } \\
\text { America }\end{array}$ & USA & $7 \%$ & $\begin{array}{l}\text { Accel } \\
\text { AFFN } \\
\text { Alaska } \\
\text { Option } \\
\text { CU24 } \\
\text { Jeanie } \\
\text { MAI } \\
\text { NYCE } \\
\text { Presto } \\
\text { Pulse } \\
\text { Shazam } \\
\text { Star } \\
\text { MC } \\
\text { Visa } \\
\end{array}$ & $\begin{array}{l}\text { Domestic/MC: set by } \\
\text { network management }\end{array}$ & Increasing & Increasing & $\begin{array}{l}\text { Some banks } \\
\text { charge per- } \\
\text { transaction } \\
\text { fees }\end{array}$ \\
\hline \multirow{6}{*}{ Europe } & $\begin{array}{l}\text { EU cross- } \\
\text { border }\end{array}$ & nap & MC & $\begin{array}{l}\text { MC: collectively set by } \\
\text { members of the network } \\
\text { Visa: collectively set by } \\
\text { members of the network } \\
\text { subject to regulatory } \\
\text { agreement }\end{array}$ & $\begin{array}{l}\text { Visa: } \\
\text { Declined }\end{array}$ & nap & nap \\
\hline & Denmark & $53 \%$ & $\begin{array}{l}\text { Dankort } \\
\text { MC } \\
\text { Visa }\end{array}$ & $\begin{array}{l}\text { Dankort: set by regulation } \\
\text { MC/Visa:aligned with } \\
\text { MSCs, which are subject } \\
\text { to regulatory cap }\end{array}$ & $\begin{array}{l}\text { Dankort: } \\
\text { Zero to } \\
\text { positive to } \\
\text { zero } \\
\text { MC: Declined } \\
\text { Visa: } \\
\text { Declined }\end{array}$ & $\begin{array}{l}\text { Dankort: } \\
\text { Zero to } \\
\text { positive to } \\
\text { zero } \\
\text { MC: Declined } \\
\text { Visa: } \\
\text { Declined }\end{array}$ & \\
\hline & $\begin{array}{l}\text { Nether- } \\
\text { lands }\end{array}$ & $31 \%$ & $\begin{array}{l}\text { Interpay } \\
\text { MC* }^{*}\end{array}$ & Interpay: sets it at zero & $\begin{array}{l}\text { Interpay: } \\
\text { Zero }\end{array}$ & Declining & \\
\hline & Spain & neg & nap & nap & nap & nap & nap \\
\hline & Sweden & $51 \%+$ & $\begin{array}{l}\mathrm{MC} \\
\text { Visa }\end{array}$ & $\begin{array}{l}\text { MC/Visa: negotiated } \\
\text { bilaterally }\end{array}$ & & & \\
\hline & UK & $28 \%+$ & $\begin{array}{l}\mathrm{MC} \\
\text { Visa }\end{array}$ & $\begin{array}{l}\text { MC: set by S2 Card } \\
\text { Services } \\
\text { Visa: collectively set by } \\
\text { members of the network }\end{array}$ & & & \\
\hline
\end{tabular}

\section{Table 3: PIN-based debit card}

Notes: 1. "*" denotes networks that issue cards to that country's residents for international use and are available for foreigner's use within the country. 2. "+" indicates share includes Signature-based transactions. 3. "nap" denotes not applicable. 4. "neg" denotes negligible. 


\begin{tabular}{|c|c|c|c|c|c|c|}
\hline \multirow[b]{2}{*}{ Region } & \multirow[b]{2}{*}{ Country } & \multicolumn{4}{|c|}{ Network Rules } & \multirow[b]{2}{*}{ Issues } \\
\hline & & $\begin{array}{l}\text { No- } \\
\text { Surcharge } \\
\end{array}$ & HAC & Net Issuer & \begin{tabular}{|l|} 
Duality / \\
Exclusion \\
\end{tabular} & \\
\hline 1 & 2 & 9 & 10 & 11 & 12 & 13 \\
\hline $\begin{array}{l}\text { Asia } \\
\text { Pacific }\end{array}$ & Australia & Visa: Yes & nap & & Yes & $\begin{array}{l}\text { Reserve Bank of Australia proposal to lower } \\
\text { EFTPOS interchange fees. }\end{array}$ \\
\hline \multirow{6}{*}{$\begin{array}{l}\text { North } \\
\text { America }\end{array}$} & Canada & $\begin{array}{l}\text { Interac: } \\
\text { No }\end{array}$ & nap & MC: Yes & No & $\begin{array}{l}\text { Some discussions over efficacy of zero interchange } \\
\text { system. }\end{array}$ \\
\hline & Mexico & nap & nap & nap & nap & nap \\
\hline & \multirow{4}{*}{ USA } & \multirow{4}{*}{$\begin{array}{l}\text { MC/Visa: } \\
\text { Yes }\end{array}$} & \multirow{4}{*}{ nap } & \multirow{4}{*}{ MC: No } & \multirow{4}{*}{ Yes } & 1. Consolidation of PIN networks. \\
\hline & & & & & & $\begin{array}{l}\text { 2. Interchange fees rising in apparent competitive } \\
\text { response to high and rising signature-debit } \\
\text { interchange fees. }\end{array}$ \\
\hline & & & & & & 3. Appearance of "PIN" (per-transaction user) fees. \\
\hline & & & & & & $\begin{array}{l}\text { 4. Appearance of volume-based interchange fee } \\
\text { tiers. }\end{array}$ \\
\hline \multirow{12}{*}{ Europe } & \multirow{5}{*}{$\begin{array}{l}\text { EU cross- } \\
\text { border }\end{array}$} & \multirow{3}{*}{ MC: No } & \multirow{5}{*}{ nap } & \multirow{3}{*}{ MC: No } & \multirow{5}{*}{ nap } & $\begin{array}{l}\text { 1. Visa agreement to reduce cross-border } \\
\text { interchange fees. }\end{array}$ \\
\hline & & & & & & $\begin{array}{l}\text { 2. Visa's no-surcharge and net issuer rules left intact } \\
\text { by EC. }\end{array}$ \\
\hline & & & & & & 3. MasterCard's interchange fees under EC review. \\
\hline & & \multirow[t]{2}{*}{ Visa: Yes } & & \multirow[t]{2}{*}{ Visa: Yes } & & $\begin{array}{l}\text { 4. Exclusion provisions in Visa's membership rules } \\
\text { under EC review. }\end{array}$ \\
\hline & & & & & & 5. MC eliminated its no-surcharge rule. \\
\hline & \multirow[t]{2}{*}{ Denmark } & \multirow[t]{2}{*}{$\begin{array}{l}\text { Dankort: } \\
\text { Yes }\end{array}$} & \multirow[t]{2}{*}{ nap } & \multirow[t]{2}{*}{ MC: No } & \multirow[t]{2}{*}{ Yes } & $\begin{array}{l}\text { 1. The } 2003 \text { amendment to the Payments Act } \\
\text { introduced positive interchange fees on Dankort } \\
\text { chip PIN debit transactions from January } 2005 \text {. } \\
\text { Beginning March 2005, banks are prohibited from } \\
\text { charging merchants interchange fees/MSCs for } \\
\text { Dankort transactions; instead, banks are allowed to } \\
\text { charge annual fees. Surcharging for Dankort } \\
\text { transactions has also been prohibited since March } \\
\text { 2005. }\end{array}$ \\
\hline & & & & & & $\begin{array}{l}\text { 2. The amendment reduced MSCs for MC and Visa } \\
\text { PIN transactions. }\end{array}$ \\
\hline & \multirow{2}{*}{$\begin{array}{l}\text { Nether- } \\
\text { lands }\end{array}$} & \multirow[t]{2}{*}{ No } & \multirow[t]{2}{*}{ nap } & \multirow[t]{2}{*}{ MC: No } & \multirow[t]{2}{*}{ nap } & $\begin{array}{l}\text { 1. NMa fined Interpay and member banks for } \\
\text { "charging excessive rates"; objection process still } \\
\text { underway. }\end{array}$ \\
\hline & & & & & & $\begin{array}{l}\text { 2. Issuers discussing possiblity of charging positive } \\
\text { interchange fees for Interpay transactions. }\end{array}$ \\
\hline & Spain & nap & nap & nap & nap & nap \\
\hline & Sweden & Visa: Yes & nap & MC: No & Yes & \\
\hline & UK & Yes & nap & Yes & Yes & $\begin{array}{l}\text { Switch and Solo consolidated into MasterCard } \\
\text { (Maestro). }\end{array}$ \\
\hline
\end{tabular}

Table 3: PIN-based debit card (cont.) 
(the domestic network) were introduced at the beginning of this year but have since been eliminated again, all due to regulatory actions. ${ }^{18}$ In the United States, PIN interchange fees have been drifting up, as shown in Chart 3, along with MasterCard and Visa signature debit fees. ${ }^{19}$

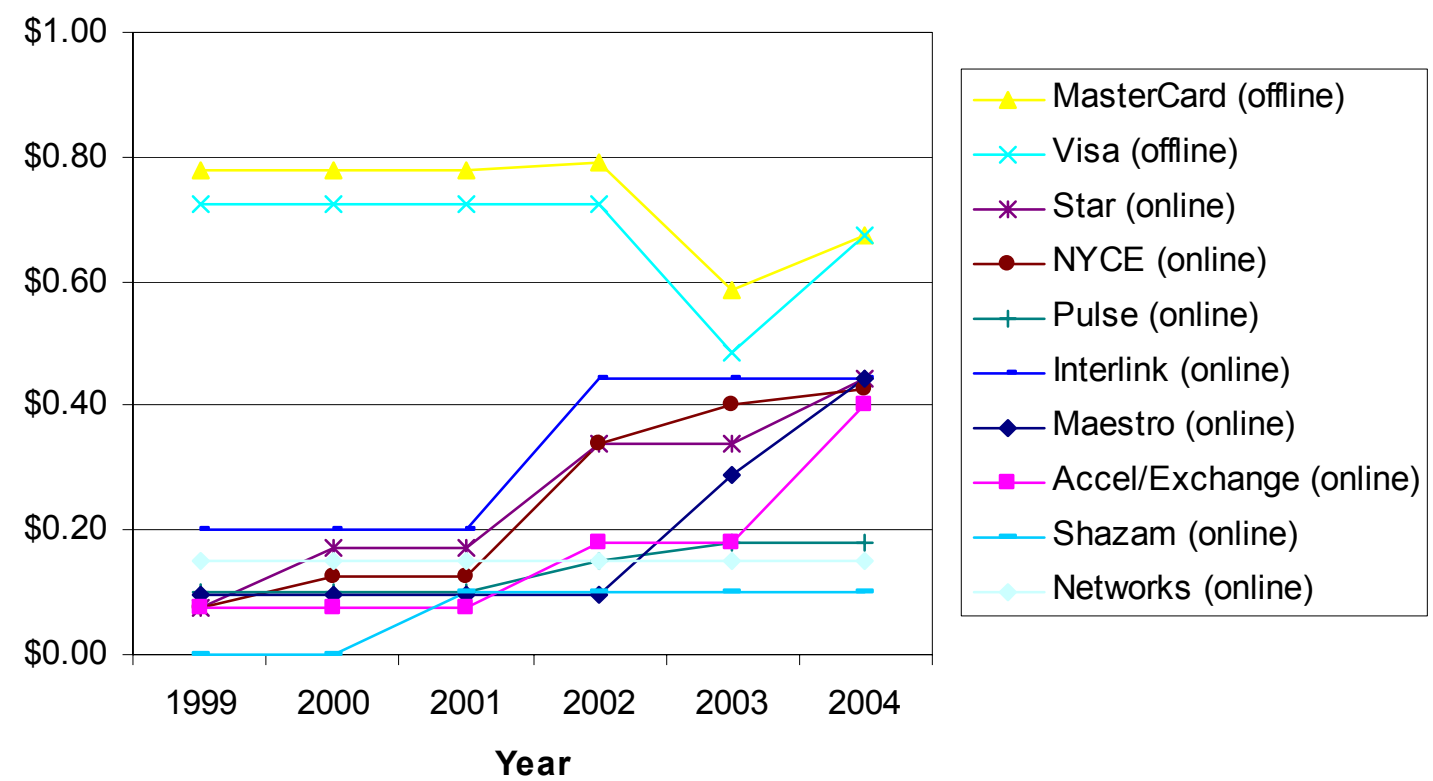

\section{Chart 3: Interchange fees for a \$50 transaction at non-supermarket: 1999-2004}

Note: Adapted from Hayashi (2004), “A Puzzle of Card Payment Pricing: Why Are Merchants Still Accepting Card Payments?" Federal Reserve Bank of Kansas City Payments System Research WP04-02, p.4. The nonsupermarket default rates are shown.

Sources: American Banker and ATM \& Debit News.

As with credit cards and signature debit, a number of PIN debit issues are currently under discussion (column 13). The Reserve Bank of Australia has proposed lowering EFTPOS interchange fees. The EC is reviewing MasterCard's cross-border interchange fees. In Canada, cards from participating issuers can now be used at U.S. merchants who belong to the NYCE network. In the United States, merchants are dissatisfied with rising interchange fees; the United States has seen a striking consolidation of domestic networks in recent years, the outcome of which is still unclear. In the Netherlands, the Competition Authority recently fined Interpay for its pricing policies, although the objection process is still underway. And in Denmark, since March 1 of this year, surcharging has been eliminated on Dankort transactions.

\subsection{Public authority involvement}

Virtually all central banks have general oversight responsibility for the payments systems of their respective countries and areas. Explicitly or implicitly, most have a mandate to ensure that

\footnotetext{
${ }^{18}$ A further review of Dankort fees is possible by summer 2005.

${ }^{19}$ After rising in 2004, some signature interchange fees were lowered in April 2005. Most remain above postsettlement levels, however.
} 
payments systems operate safely and efficiently. As retail payments systems around the globe migrate from paper to electronics - and, in particular, as credit and especially debit card transactions become a dominant form of payment - central banks are paying increasing attention to credit and debit card industries.

In most countries, however, specific interchange-fee and other payment competition issues fall under the jurisdiction of competition (regulatory and antitrust) authorities. There are exceptions, of course: the Reserve Bank of Australia and Banco de Mexico have been very visible in interchange matters. And the Banco de Espana plays an important monitoring role. But for the most part, it is the competition authorities that have taken the lead in evaluating and, at times, bringing about change, in credit and debit card markets. For the set of countries under review in this paper, this is true of Canada, the United States, EU cross-border, Denmark, the Netherlands, Spain, Sweden, and the UK.

Turning to specifics, Table 4 documents various actions taken by and pending before public authorities on interchange and related issues. Beginning with Australia, in early 2003, the Reserve Bank of Australia (RBA) eliminated credit card no-surcharge rules, and later that year mandated that credit card interchange fees be lowered. Early this year, it ruled that payments between American Express and Diners Club and their bank partners will not be regulated but that the two companies will reword certain restrictive clauses in their merchant agreements. American Express and Diners Club are now publishing their average merchant service fees; Bankcard, MasterCard, and Visa have been required to publish interchange fees since 2003.

Pending issues include RBA proposals to lower EFTPOS PIN debit interchange fees and Visa signature debit interchange fees. The RBA also has proposed eliminating the honor-allcards rule (HAC) linking Visa's credit and signature debit cards. The Bank will review existing regulations for credit card schemes in 2007.

The Banco de Mexico is the other central bank that has taken a prominent role in addressing credit and debit card issues. It has been working with the Mexican Bankers Association to lower interchange fees and make the HAC rule more flexible.

Among competition authorities, the European Commission in 2001 came to an agreement with Visa whereby Visa agreed to gradually reduce its cross-border interchange fees on credit cards and signature and PIN debit cards by December 2007. At the same time, Visa was permitted to keep its no-surcharge, HAC, and net issuer rules. Currently pending are EC investigations of MasterCard cross-border interchange fees and exclusion provisions in Visa membership rules.

In the UK, the Office of Fair Trading (OFT) ruled in September 2005 that the 2000-2004 MasterCard multilateral credit card interchange fee agreements were anti-competitive; MasterCard is currently appealing this decision. In October of 2005, the OFT issued a statement of objections against Visa's domestic multilateral interchange fee agreements for its credit, deferred debit, and charge card transactions. A period of discussion is currently underway.

Competition authorities have been active elsewhere as well. Last year, the Netherlands Competition Authority (NMa) fined Interpay and its member banks for charging "excessive" merchant service charges, although the objection process is still underway. Also last year, the United States Supreme Court upheld the U.S. Department of Justice's successful 2001 court case eliminating MasterCard and Visa exclusion rules that prohibited member banks from issuing 


\begin{tabular}{|c|c|c|c|c|}
\hline & \multirow{2}{*}{\multicolumn{3}{|c|}{ Competition Authority }} \\
\hline & & & & \\
\hline Region & Country & Agency & Actions/Rulings Taken & Action/Rulings Pending \\
\hline 1 & 2 & 3 & 4 & 5 \\
\hline $\begin{array}{l}\text { Asia } \\
\text { Pacific }\end{array}$ & Australia & $\begin{array}{l}\text { Australian } \\
\text { Competition and } \\
\text { Consumer } \\
\text { Commission (ACCC) }\end{array}$ & & \\
\hline \multirow{3}{*}{$\begin{array}{l}\text { North } \\
\text { America }\end{array}$} & Canada & Competition Bureau & $\begin{array}{l}\text { Reached a Consent Agreement with the principal } \\
\text { members of Interac, which resulted in expanded } \\
\text { representation on the Board, liberalization of } \\
\text { network access rules, and removal of constraints } \\
\text { on product innovation and price competition, } \\
\text { including the removal of the prohibition against } \\
\text { surcharging. }\end{array}$ & \\
\hline & Mexico & $\begin{array}{l}\text { Comision Federal de } \\
\text { Competencia (Federal } \\
\text { Competition } \\
\text { Commissioin) } \\
\end{array}$ & & \\
\hline & USA & Department of Justice & $\begin{array}{l}\text { Won court case eliminating MC and Visa } \\
\text { exclusion rules that prohibited member banks from } \\
\text { issuing American Express and Discover credit } \\
\text { cards }(10 / 04) \text {. }\end{array}$ & \\
\hline \multirow{9}{*}{ Europe } & & & $\begin{array}{l}\text { In “Case No COMP/29.373, Visa International- } \\
\text { Multilateral Interchange Fee," }\end{array}$ & $\begin{array}{l}\text { 1. MC interchange fees under } \\
\text { investigation }(10 / 03) .\end{array}$ \\
\hline & $\begin{array}{l}\text { EU cross- } \\
\text { border }\end{array}$ & European Commission & $\begin{array}{l}\text { (i)Visa agreed to gradually reduce cross-border } \\
\text { interchange fees on credit card, signature debit, } \\
\text { and PIN debit transactions by December } 2007 \text { and } \\
\text { to publish these fees, and (ii) the EC stated that it } \\
\text { had no grounds for prohibiting Visa's no-surcharge } \\
\text { and net issuer rules }(08 / 01) \text {. }\end{array}$ & $\begin{array}{l}\text { 2. Exclusion provisions in Visa } \\
\text { membership rules under } \\
\text { investigation }(08 / 04) \text {. }\end{array}$ \\
\hline & Denmark & $\begin{array}{l}\text { Konkurrencestyrelsen } \\
\text { (Danish Competition } \\
\text { Authority) }\end{array}$ & $\begin{array}{l}\text { Helps administer the Danish Act on Certain } \\
\text { Payments (2000) and the amendment to the Act } \\
(2003) \text {. The Act (2000) regulates MSCs, and } \\
\text { allows for merchant surcharging. The amendment } \\
\text { (2003) mandated the introduction of a positive } \\
\text { interchange fee on Dankort chip PIN debit } \\
\text { transactions, and a reduction in MC and Visa PIN } \\
\text { debit MSCs. }\end{array}$ & \\
\hline & $\begin{array}{l}\text { Nether- } \\
\text { lands }\end{array}$ & $\begin{array}{l}\text { Netherlands } \\
\text { Competition Authority } \\
\text { (NMa) }\end{array}$ & $\begin{array}{l}\text { NMa fined Interpay and member banks for } \\
\text { "charging excessive rates"; objection process still } \\
\text { underway (2004). }\end{array}$ & \\
\hline & \multirow[t]{2}{*}{ Spain } & $\begin{array}{l}\text { Servicio de Defensa } \\
\text { de la Competencia } \\
\text { (SDC), Tribunal de } \\
\text { Defensa de la } \\
\text { Competencia (TDC), } \\
\text { both under Ministry of } \\
\text { the Economy }\end{array}$ & \multirow[t]{2}{*}{$\begin{array}{l}\text { Agreements among banks, networks, merchants, } \\
\text { and Minsistry of the Economy have led to } \\
\text { reduction in credit card and signature debit card } \\
\text { interchange fees since } 1999 \text {. }\end{array}$} & \multirow[t]{2}{*}{$\begin{array}{l}\text { A further lowering of fees may } \\
\text { result from an April } 2005 \text { ruling by } \\
\text { the Tribunal de Defensa de la } \\
\text { Competencia. }\end{array}$} \\
\hline & & Ministry of Industry & & \\
\hline & Sweden & $\begin{array}{l}\text { Swedish Competiton } \\
\text { Authority }\end{array}$ & & \\
\hline & \multirow[t]{2}{*}{ UK } & \multirow{2}{*}{$\begin{array}{l}\text { Office of Fair Trading } \\
\text { (OFT) }\end{array}$} & & $\begin{array}{l}\text { 1. Following multiyear } \\
\text { investigation, OFT issued a decision } \\
\text { that MC's 2000-2004 interchange } \\
\text { fee agreements restricted } \\
\text { competition and infringed on } \\
\text { competition law }(9 / 05) \text {. }\end{array}$ \\
\hline & & & & $\begin{array}{l}\text { 2. OFT issues a statement of } \\
\text { objections against Visa's } \\
\text { interchange fees including credit } \\
\text { cards, deferred debit, and charge } \\
\text { card transactions }(10 / 05) \text {. }\end{array}$ \\
\hline
\end{tabular}

Table 4: Public authority involvement 


\begin{tabular}{|c|c|c|c|c|c|}
\hline & & Central Bank & & & Competition Authority / \\
\hline Region & Country & Agency & Actions/Rulings Taken & Actions/Rulings Pending & Central Bank Interaction \\
\hline 1 & 2 & 6 & 7 & 8 & 9 \\
\hline \multirow{4}{*}{$\begin{array}{l}\text { Asia } \\
\text { Pacific }\end{array}$} & \multirow{4}{*}{ Australia } & \multirow{2}{*}{$\begin{array}{l}\text { Reserve Bank } \\
\text { of Australia }\end{array}$} & $\begin{array}{l}\text { 1. MC, Visa, American Express, } \\
\text { and Diners Club credit card no- } \\
\text { surcharge rules eliminated }(01 / 03) \text {. }\end{array}$ & $\begin{array}{l}\text { 1. Proposed lowering } \\
\text { EFTPOS PIN debit } \\
\text { interchange fees }(02 / 05) \text {. }\end{array}$ & \multirow{4}{*}{$\begin{array}{l}\text { Conducted joint study, } \\
\text { "Debit and credit card } \\
\text { schemes in Australia, a } \\
\text { study of interchange fees } \\
\text { and access," October } 2000 .\end{array}$} \\
\hline & & & $\begin{array}{l}\text { 2. Bankcard, MC, and Visa } \\
\text { lowered credit card interchange } \\
\text { fees and began publishing } \\
\text { interchange fee levels }(10 / 03) \text {. }\end{array}$ & $\begin{array}{l}\text { 2. Proposed lowering Visa } \\
\text { signature debit interchange } \\
\text { fees }(02 / 05) \text {. }\end{array}$ & \\
\hline & & \multirow[b]{2}{*}{$\begin{array}{l}\text { Payments } \\
\text { System Board }\end{array}$} & $\begin{array}{l}\text { 3. Payments between American } \\
\text { Express and Diners Club and their } \\
\text { bank parters will not be regulated; }\end{array}$ & $\begin{array}{l}\text { 3. Proposed eliminating Visa } \\
\text { credit card-signature debit } \\
\text { card HAC rule }(02 / 05) \text {. }\end{array}$ & \\
\hline & & & $\begin{array}{l}\text { however, American Express and } \\
\text { Diners Club will reword clauses in } \\
\text { their merchant aggrements and } \\
\text { publish average merchant service } \\
\text { fees }(02 / 05) \text {. }\end{array}$ & $\begin{array}{l}\text { 4. Bank will review the } \\
\text { standards for credit card } \\
\text { schemes in } 2007(02 / 05) \text {. }\end{array}$ & \\
\hline \multirow{5}{*}{$\begin{array}{l}\text { North } \\
\text { America }\end{array}$} & Canada & $\begin{array}{l}\text { Bank of } \\
\text { Canada }\end{array}$ & & & Limited interaction. \\
\hline & & & & $\begin{array}{l}\text { 1. Interchange fees have been } \\
\text { reduced due to a concerted } \\
\text { effort between Banco de } \\
\text { Mexico and the Mexican } \\
\text { Bankers Association. }\end{array}$ & \multirow{3}{*}{ Limited interaction. } \\
\hline & Mexico & $\begin{array}{l}\text { Banco de } \\
\text { Mexico }\end{array}$ & & $\begin{array}{l}\text { 2. Banco de Mexico has } \\
\text { made the HAC rule more } \\
\text { flexible: merchants are } \\
\text { allowed to accept only debit, } \\
\text { credit, or both cards. }\end{array}$ & \\
\hline & & & & $\begin{array}{l}\text { 3. The no-surcharge rule was } \\
\text { left intact because discounts } \\
\text { are already allowed. }\end{array}$ & \\
\hline & USA & $\begin{array}{l}\text { Federal } \\
\text { Reserve }\end{array}$ & & & Limited interaction. \\
\hline \multirow{6}{*}{ Europe } & $\begin{array}{l}\text { EU cross- } \\
\text { border }\end{array}$ & $\begin{array}{l}\text { European } \\
\text { Central Bank }\end{array}$ & & & $\begin{array}{l}\text { Some interaction; ECB can } \\
\text { play advisory role. }\end{array}$ \\
\hline & Denmark & $\begin{array}{l}\text { Danmarks } \\
\text { Nationalbank }\end{array}$ & & & Limited interaction. \\
\hline & $\begin{array}{l}\text { Nether- } \\
\text { lands }\end{array}$ & $\begin{array}{l}\text { De } \\
\text { Nederlandsche } \\
\text { Bank }\end{array}$ & & & Limited interaction. \\
\hline & Spain & $\begin{array}{l}\text { Banco de } \\
\text { Espana }\end{array}$ & & $\begin{array}{l}\text { Banco de Espana monitoring } \\
\text { credit card market; first } \\
\text { public report due shortly. }\end{array}$ & $\begin{array}{l}\text { TDC and Banca de Espana } \\
\text { work together on occasion. }\end{array}$ \\
\hline & Sweden & Riksbank & & & Limited interaction. \\
\hline & UK & $\begin{array}{l}\text { Bank of } \\
\text { England }\end{array}$ & & & $\begin{array}{l}\text { Limited interaction; Bank of } \\
\text { England sits as an observer } \\
\text { on joint OFT/industry task } \\
\text { force. }\end{array}$ \\
\hline
\end{tabular}

\section{Table 4: Public authority involvement (cont.)}


American Express and Discover credit cards. Earlier actions or agreements in other countries include: (i) the Danish Competition Authority's administration of the 2003 Amendment to the Danish Act on Certain Payments, whereby MasterCard and Visa PIN debit merchant service charges were reduced and a positive (non-zero) interchange fee was introduced on Dankort chip PIN debit card transactions; ${ }^{20}$ (ii) the Canadian Competition Authority's mid-90's Consent Agreement with the principal member of Interac, which resulted in expanded representation on the Board, liberalization of network access rules, and removal of constraints on product innovation and price competition, including the removal of the prohibition against surcharging; and (iii) the Spanish Ministry of the Economy's 1999 agreement with banks, networks, and merchants to lower credit card and signature debit card interchange fees, and the Tribunal's 2005 request to the networks for new interchange fee setting procedures.

Interaction among competition authorities and central banks on credit and debit card issues varies across countries (column 9). In some countries, there is some degree of consultation and occasional representation on joint task forces - this is, or has been, true in Spain, the EC, the UK, and Australia, for example. In other countries, the degree of interaction between competition authority and central bank appears limited, at least formally. Whether closer ties will be forged in light of the issues facing the card industry bears watching.

\section{Determinants of interchange fees}

Section 3 showed the considerable variation that exists across countries in interchange fee arrangements in credit and debit card markets. Section 2 explored the potential role played by interchange fees in affecting the structure of prices faced by cardholders and merchants in these two-sided markets. This framework provides a natural starting point for analyzing some of the possible determinants of interchange fees. Drawing on the economics literature on the subject ${ }^{21}$, this section outlines various factors which in theory could affect interchange fees. It then examines some preliminary empirical evidence on the matter.

\subsection{Theoretical determinants}

The simplest models of interchange fee determination assume that merchants are non-strategic in their decision about whether to accept cards or not. ${ }^{22}$ Like monopolistic merchants, these merchants accept cards only if the (net) transactional benefits of doing so exceed the amount they have to pay. ${ }^{23}$ In particular, non-strategic merchants do not consider that accepting cards

\footnotetext{
${ }^{20}$ See Table 3 column 13 (Issues) of Denmark for details.

${ }^{21}$ Specifically, see the publications of Rochet and Tirole (2002), Schmalensee (2002) and Wright (2004) who offer models of how interchange fees are determined in the case of a single card association. See Rochet and Tirole (2003a) and Guthrie and Wright (2003) for equivalent models in the case of competing payment schemes. Baxter (1983) provides a much earlier analysis of interchange fees, but his analysis is normative rather than positive, and so he does not provide a theory of the determinants of interchange fees. Rochet (2003) provides a synthesis of these and other theories. For more general surveys see Chakravorti (2003) and Hunt (2003).

${ }^{22}$ For instance, Baxter (1983) and Schmalensee (2002) implicitly make this assumption.

${ }^{23}$ Net transactional benefits are defined as the benefits of conducting a transaction with a payment card (for example, payment guarantees, immediate fund availability) less the difference between the benefits and costs of conducting a transaction with alternative payment types, for example, cash and checks and accompanying handling and fraud costs. Note the theory allows the possibility that merchants obtain negative net benefits of accepting cards,
} 
may be a way of attracting customers from rival merchants. ${ }^{24}$ This unrealistic assumption has been relaxed in other works, the implications of which will be discussed below. Assuming that consumers pay the same price regardless of whether they use a card or not, consumers hold and use cards if the (net) transactional benefits they obtain from doing so exceed the fee they have to pay. ${ }^{25}$ By specifying the (net) transactional benefits to cardholders and merchants, the demand from each type of user is determined.

In such models, a single card association sets an interchange fee to maximize some objective such as the aggregate profits of its members, or the total volume of card transactions. Profits are determined by the fees collected over all cardholders and merchants, and over all their card transactions. The nature of issuing and acquiring competition, together with the costs of issuing and acquiring, then determine exactly how interchange fees feed through into cardholder and merchant fees, and hence the number of card transactions and profits the members attract.

\subsubsection{Balancing considerations}

Schmalensee (2002) and Wright (2004) provide a formal analysis that fits this case. ${ }^{26}$ The interchange fee that results primarily reflects balancing considerations. In particular, the card association seeks to maximize card transactions by attracting the right balance of cardholder demand and merchant acceptance. The choice of interchange fee will not be optimal if there is very high demand from cardholders but few merchants that are willing to accept cards. Similarly, interchange fees will not be optimal if there is little demand from cardholders even though all merchants are willing to accept cards. As a result, the key determinants of privately set interchange fees emphasized by this framework reflect any asymmetries between the two sides of the business.

Specifically, Schmalensee (2002) finds higher issuing costs or demand by merchants result in higher interchange fees and higher acquiring costs or demand by cardholders result in lower interchange fees. Interchange revenue will flow to the high cost side of the business, and to the side which has less demand. ${ }^{27}$ To understand this result, consider a situation where suddenly the cost of issuing increases but other factors remain unchanged. This implies that cardholders will face higher fees (or reduced benefits). This will reduce the number of cardholders, and the extent of card usage. All else equal, there will now be too little demand for card usage relative to merchants that accept cards from the perspective of a card association that seeks to maximize the volume of card transactions. That is, to reach the balance of card usage and merchant acceptance

\footnotetext{
although without the strategic motivation for accepting cards, these merchants would not be willing to pay any positive merchant fee.

${ }^{24}$ This is plausible if merchants do not face competition for their services, or if most of the merchant's customers are one-off and do not know whether the particular merchant accepts cards before deciding whether to purchase at its premises.

${ }^{25}$ Net transactional benefits are defined as the benefits consumers obtain from using cards (for example, convenience) less the difference between the benefits and costs of using alternative payment types, for example, cash and checks and accompanying time and risk-of-theft costs.

${ }^{26}$ Schmalensee's model is based on merchants being non-strategic, while Wright allows merchants to accept cards for strategic reasons.

${ }^{27}$ This implies that the interchange fee will, other things equal, tend to balance the costs of issuers and acquirers. However, it is important to note that this is not equivalent to the view sometimes made that interchange fees are needed by issuers to recoup their higher costs. Even with a zero interchange fee, issuers will cover their cost, in equilibrium by charging cardholders more. Rather, the point of equalizing issuers and acquirers costs emphasized by the balancing approach is to achieve the appropriate structure of cardholder and merchant fees from the perspective of the card association.
} 
that maximizes the volume of card transactions and so the profits of the members of the card association, card fees need to be decreased relative to merchant fees. A higher interchange fee does exactly this. A shift downwards in cardholder demand has the same effect. In contrast, higher acquiring costs or lower merchant demand has the opposite effect and calls for a decrease in interchange fees.

Wright (2004) finds the same results in a model in which the underlying transactional benefits of card usage and card acceptance are specified, and which allows merchants to accept cards for strategic reasons. In this case, interchange fees decrease in the transactional benefits obtained by cardholders from using cards and increase in the transactional benefits obtained by merchants of accepting cards. The transactional benefits of cardholders can be thought of as another measure for the level of cardholder demand (and likewise for merchants). Wright also finds that the interchange fee increases in the price-cost margin of issuers and decreases in the price-cost margins of acquirers. The effect of higher issuer margins is to increase card fees, and so like higher issuer costs, this requires higher interchange fees to optimally balance the two sides of the market so as to maximize the volume of card transactions and profits for the card association as a whole.

None of these models incorporates the possible use of interchange fees to spur investment by issuers or acquirers. It is possible that interchange fees could promote greater investment on one side of the market or another. This arises if the pass-through of interchange fees to end-users is less than perfect so that issuers and acquirers retain some profits, and interchange fees can affect these profits directly. ${ }^{28}$ In this case, an increase in the interchange fee will increase issuers' profits, making issuers more likely to promote (and possibly invest in) the development of the particular card network. Thus, another possible explanation of what drives interchange fees is that they are set in part to give incentives for investment activity on one side relative to the other. This is just another example of the interchange fee acting as a balancing instrument. ${ }^{29}$

\subsubsection{Shifting revenues to issuers}

In addition to these balancing effects, these models also capture the possible use of interchange fees to shift revenues from acquirers to issuers. This can arise for two reasons. One possibility, first raised by Schmalensee (2002), is that issuers are more powerful members of card associations, and so hold more voting power than acquirers in negotiating the interchange fee. If issuers get to retain some of the higher interchange revenue obtained from any increase in interchange fees, the card association may then end up setting interchange fees higher than is optimal from a balancing perspective. Some card transactions will be sacrificed by setting an interchange fee that is too high (from the perspective of issuers and acquirers jointly) so as to shift revenue to issuers.

The second possibility, also raised by Schmalensee (2002), is that one side of the market is more competitive than the other. The case he discusses involves acquiring being perfectly competitive while issuing involving market power. Rochet and Tirole (2002) also consider a similar setting. Since costs are fully passed through on the acquiring side, but revenues are not fully competed away on the issuing side, a higher interchange fee may generate higher fees (in total) and so higher profits for members as a whole. Wright (2004) notes that it is the relative

\footnotetext{
${ }^{28}$ Of course, interchange fees also affect the profits of issuers and acquirers indirectly by influencing the demand from cardholders and merchants and so the volume of card transactions.

${ }^{29}$ If alternatively, lower price-cost margins lead firms to innovate in order to maintain margins, then a lower interchange fee could be used to spur such innovation in issuing relative to acquiring.
} 
degree of pass-through of interchange fees that matters here. Even if issuing is profitable and acquiring is not, if any increase in interchange fees results in an equal (or greater) decrease in card fees (or increase in cardholder benefits), then issuers and acquirers do not have any joint incentive to set high interchange fees to shift revenues to issuers. Thus, the relative degree of pass-through by issuers and acquirers is another potential determinant of interchange fees. As a result, the theory predicts privately set interchange fees should increase in the extent of acquirer pass-through and decrease in the extent of issuer pass-through. ${ }^{30}$

\subsubsection{Merchant and inter-system competition}

Up to this point, the analysis has focused on a model which ignores two important types of competition. One is competition between merchants that accept cards (Rochet and Tirole, 2002; and Wright, 2004). The other is competition between different payment systems (Rochet and Tirole, 2003; Guthrie and Wright, 2003; and Guthrie and Wright, 2005).

Considering merchant competition first, merchants will accept cards, in part, to attract customers from each other. This will increase the amount they will be prepared to pay to accept cards above that determined solely from any transactional benefits they obtain from accepting cards. From the perspective of the card association, this is like an increase in demand from merchants. According to the result above, higher merchant demand means the card association will want to set a higher interchange fee. The same result applies here. When merchants accept cards for strategic reasons, the interchange fee that balances demands across cardholders and merchants so as to maximize card volume and profits for the members, will be higher. Essentially, if merchants have little resistance to paying merchant fees because of their need to do so to attract customers, then card schemes will drive higher card volumes and profits by setting relatively high interchange fees.

The second form of competition missing from the simple framework above is competition with alternative payment schemes (so called inter-system competition). The effect of this form of competition on the interchange fee that will be chosen is far from obvious. It is similar to asking whether more competition between rival newspapers mean publishers will levy more of their charges on readers or more on advertisers. Greater inter-system competition should not increase the total fees charged across both sides of the market. However, it is theoretically possible for greater competition to increase or decrease the fees charged on any particular side, or leave them unchanged. Rochet and Tirole (2003a) show that with linear demands and non-strategic merchants, the structure of prices (or the interchange fee) set by a single monopoly card association can be identical to that set by two competing schemes. ${ }^{31}$ Whether interchange fees are likely to increase or decrease with inter-system competition thus depends on other factors.

There are certain situations where greater inter-system competition is likely to have a predictable impact on interchange fees. One situation is if interchange fees are being used primarily to shift revenues to issuers (say due to greater issuer bargaining power or market power). Greater inter-system competition should then reduce interchange fees. This result

\footnotetext{
${ }^{30}$ This assumes at least one side enjoys positive economic profits. If both sides obtain no economic profit regardless of the interchange fee, then there is no value in shifting revenue from one side to the other, and in fact, the level of the interchange fee is then indeterminate. In this case, it may be that the organization which runs the card association will still want to set the interchange fee to maximize the volume of card transactions so as to increase the number of transactions it can process (and therefore its revenue).

${ }^{31}$ Guthrie and Wright (2005) show that once merchants are strategic, this result no longer holds, and inter-system competition will generally affect the interchange fee in one direction or another. This result is discussed below.
} 
assumes issuers are tied to a particular card scheme and cannot move between them, a condition reconsidered below.

One way inter-system competition (say between MasterCard and Visa, or between credit cards and debit cards) can raise interchange fees is if most merchants accept both types of card and consumers typically just carry a single type of card. Then competition will cause schemes to compete to attract customers to hold their card exclusively, since merchants may continue to accept both cards given they expect consumers to only hold one type of card. This situation is one of a competitive bottleneck (Guthrie and Wright, 2003). Thus, greater inter-system competition can cause card associations to increase their interchange fees. More generally, a similar result may arise if cardholders rather than merchants ultimately determine which card will be used.

On the other hand, competition can also have the opposite effect, if most consumers tend to hold multiple cards. Then a merchant may want to reject the more expensive card knowing most consumers will still be able to pay with the other card, which they prefer to accept. Thus, strong merchants may be able to play one card scheme off against the other to push down merchant fees (and interchange fees).

Even if the role of consumers and merchants is roughly balanced in determining which card will be selected through inter-system competition, such competition can still lead to higher interchange fees. Guthrie and Wright (2005) find that in this case inter-system competition when combined with merchant competition results in higher interchange fees being set than with either form of competition on its own. Essentially, inter-system competition causes the networks to focus more on end-user surplus rather than just the number of transactions they can generate since the network that can offer the most to users will dominate. Merchant competition results in the surplus of cardholders being weighted more highly, which implies a higher interchange fee will be set when networks compete. If strong issuers can play one card association off against another, the result of inter-system competition may be to drive up interchange fees.

Given inter-system competition can in theory either increase or decrease interchange fees, it becomes an empirical issue as to the actual impact of inter-system competition on interchange fees. Likewise, the role of cost and demand asymmetries, as well as issuer and acquirers passthrough rates (and market power) are other factors that can be potentially explored empirically.

\subsection{Preliminary empirical evidence}

Unfortunately, the lack of any systematic data on interchange fees limits a serious empirical analysis of these issues. Perhaps for this reason, there is no existing empirical analysis of the determinants of interchange fees. Here the analysis is restricted to exploring whether there is any simple relationship between interchange fees and issuer (or system) market concentration. A positive relationship between interchange fees and issuer market concentration is predicted by balancing considerations (Section 4.1.1) and also so as to shift revenues to issuers (Section 4.1.2) assuming higher issuer concentration corresponds to higher market power. On the other hand, economic theory predicts inter-system competition can either increase or decrease interchange fees.

In Figure 1, the most recently available credit card interchange fees for twenty selected countries are plotted against a measure of issuer concentration (a proxy for issuer market power). The countries included are all available countries in Asia Pacific (obtained on the basis of confidentially from Visa International) in addition to Canada, the Netherlands, Spain, Sweden, the United Kingdom and the United States, for which data was obtained from various sources. 
For the case of Australia, the Netherlands, and Sweden, the interchange fee was taken at preregulation levels to avoid distorting the results. Issuer market concentration is measured as the value of card transactions handled by the five largest issuers divided by the total value of card transactions. For Asia Pacific countries, all variables are measured for the Visa network alone. For the remaining countries, the variables include data from both the MasterCard and Visa networks. $^{32}$

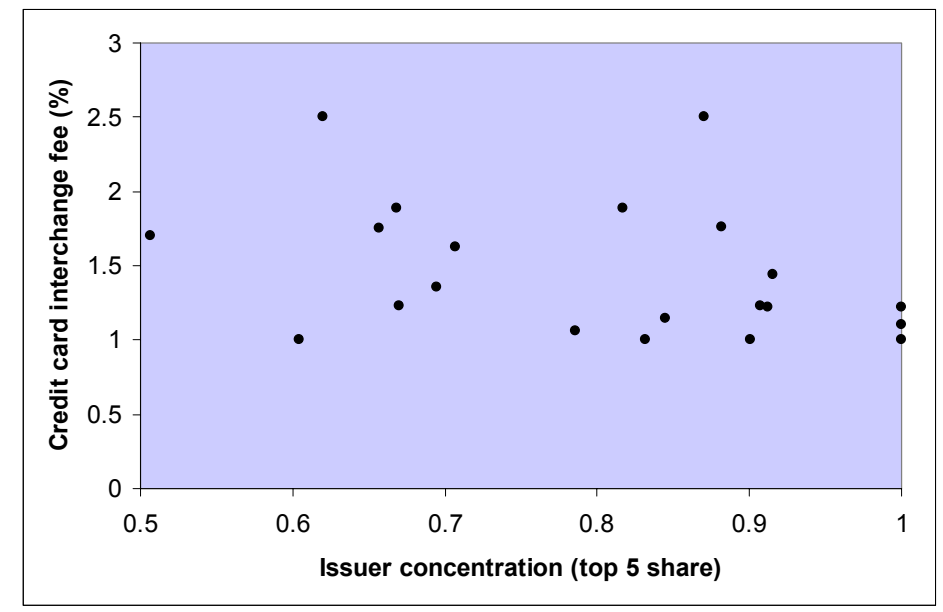

Figure 1: Interchange fee versus issuer concentration

Figure 1 reveals that there is no obvious relationship between issuer market concentration and interchange fees across the sample of countries considered. In fact, the correlation between the two variables is somewhat negative $(-0.36)$, contrary to expectations of a positive relationship. This could simply be because issuer concentration does not proxy at all for issuer market power. Even if issuer concentration does proxy for issuer market power, the finding does not rule out that such a relationship exists. Rather, it implies that any relationship must be more complex, involving several factors that determine interchange fees, such as the "balancing" factors identified in this section as well as the many country-specific factors documented in Section 3. Unless these other factors are controlled for, the true effect of issuer concentration on interchange fees cannot be uncovered.

The relationship between interchange fees and the difference between issuing concentration and acquiring concentration tells a similar story, as Figure 2 demonstrates. ${ }^{33}$ Figure 2 also reveals that acquiring is somewhat more concentrated than issuing for the majority of countries considered. This seems at odds with the assumption used in some of the theoretical work in which issuers were assumed to have market power but not acquirers. ${ }^{34}$ Of course, other factors than market concentration can determine market power. The fact acquirers have to negotiate with large retailers in private suggests they may be more competitive than concentration measures alone imply.

\footnotetext{
${ }^{32}$ Given the size of the Visa network in Asia Pacific, and the similarity of the issuers of the two networks, Visa numbers are likely to be reasonable proxies for the average interchange fee and market concentration measures obtained for MasterCard and Visa taken together.

${ }^{33}$ Acquirer concentration is measured in the same way as issuer concentration. The data for Canada, Mexico and Spain is not available for this variable, so the three countries are eliminated from the sample.

${ }^{34}$ It is also somewhat at odds with the claim that issuers have more power than acquirers in setting interchange fees.
} 
Figure 3 considers the relationship between a measure of system concentration and interchange fees. It shows that there is also no obvious relationship between interchange fees and the proportion of card transactions (in value terms) that Visa conducts compared to Visa and MasterCard together. Those countries where Visa and MasterCard equally share the market have no higher interchange fees (on average) than those where Visa attracts most of the business. Thus, the relative size of Visa to MasterCard does not seem to be related to the average level of interchange fees, unless it is part of a more complicated relationship.

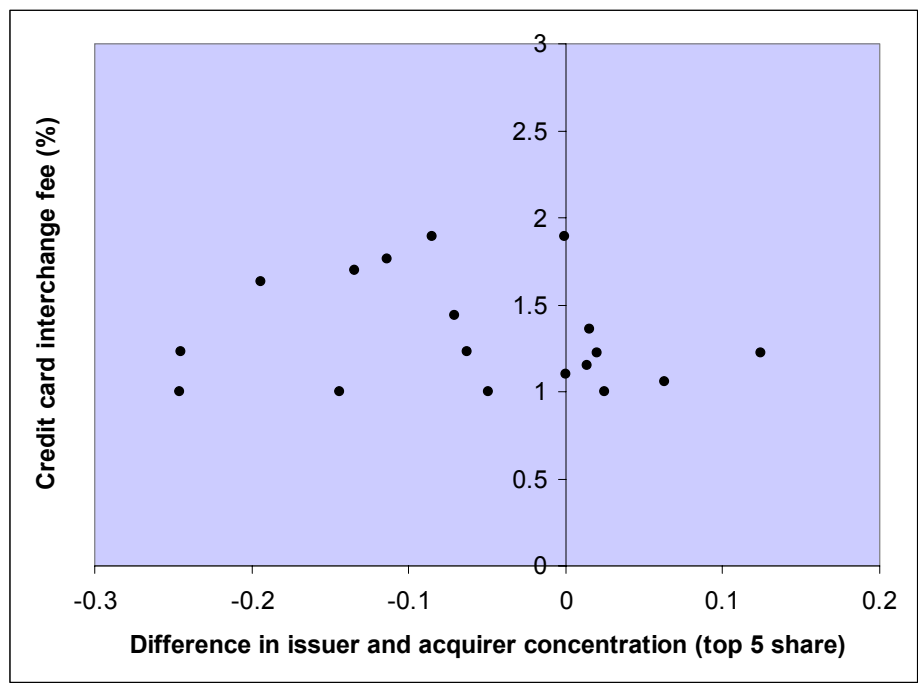

Figure 2: Interchange fee versus difference in issuer and acquirer concentration

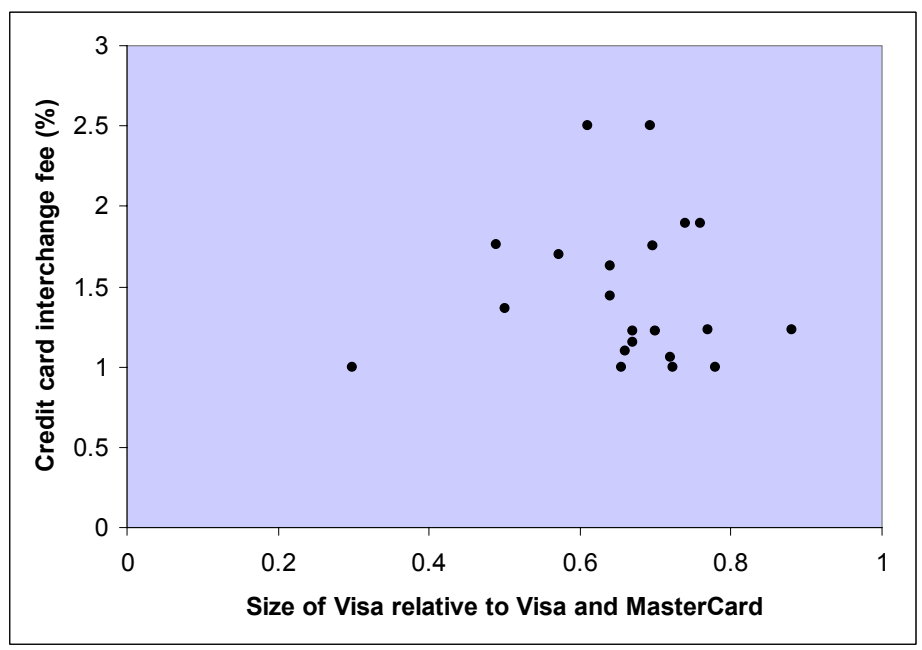

\section{Figure 3: Interchange fee versus system concentration}

Time series data on individual countries are largely lacking. One country for which there are some data is the United States. Figure 4 gives a time series plot of U.S. interchange fees and issuer concentration from 1990 to 2003. Interchange fees are averages for Visa consumer credit cards (from Visa USA), while issuer concentration measures the share of the top five issuers of 
MasterCard and Visa (in value terms) out of all MasterCard and Visa issuers (from Nilson reports). ${ }^{35}$ Figure 4 reveals an up-trend in both the top-five issuer concentration measure and average interchange fees, consistent with a positive relationship between the two variables.

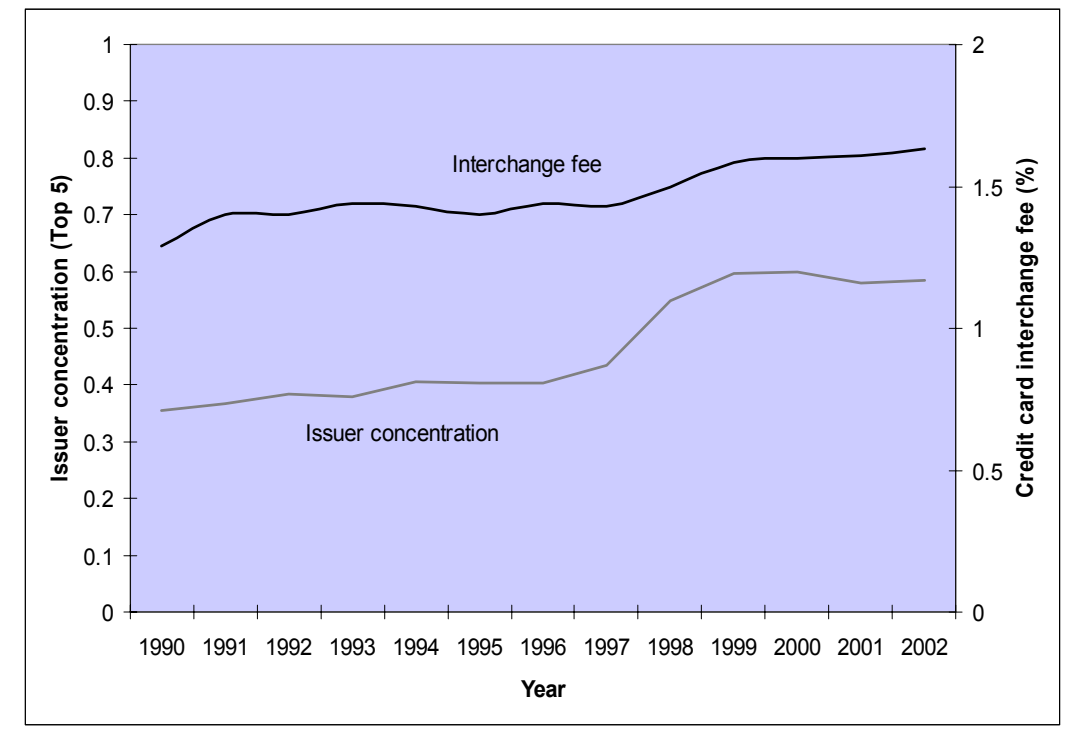

\section{Figure 4: Interchange fees and top 5 issuer concentration in the U.S.}

In comparison to cross-country data, looking at a single country across time may better control for other factors (such as the relative costs of issuing and acquiring, the extent of perceived cardholder and merchant benefits, and the availability of substitute instruments). Looking at the U.S data is also particularly interesting since there has been a fair bit of variation in the series over the available sample. In particular, there was a fairly substantial increase in the market share of the largest issuers from the mid-1990s onwards, largely reflecting merger and acquisition activity.

Consistent with the time-series pattern evident from Figure 4, the average interchange fee is highly correlated with issuer concentration over this period. ${ }^{36}$ There are several possible explanations for this. The first, based on the "balancing" approach, is that facing higher issuer concentration and price-cost margins, it is optimal for card associations to set a higher interchange fee so that card fees do not increase (or cardholder benefits do not fall) by the full extent of the higher issuing margins. A second possible explanation is that shifting revenues to the issuing side through higher interchange fees becomes more attractive (or feasible) in the face

\footnotetext{
${ }^{35}$ Using Visa's interchange fee rather than a weighted average of interchange fees for MasterCard and Visa is unlikely to change figure 4 much. MasterCard's interchange fee is likely to have moved in a similar way over the time period.

${ }^{36}$ Even with only 14 observations, the relationship appears statistically significant. A simple regression of interchange fees on a constant and the issuer concentration measure gives a coefficient on issuer concentration of 1.06 , with a t-stat of 9.11 . This simple regression predicts that the interchange fee in the absence of issuer concentration is 0.99 . However, there are potential statistical problems with such an analysis, reflecting the possibility of the series being non-stationary, concerns that are not easily addressed with such a small sample. When the series are first-differenced (to eliminate the apparent non-stationarity in each), the relationship is no longer statistically significant.
} 
of higher issuer concentration. ${ }^{37} \mathrm{~A}$ third explanation, consistent with inter-system competition resulting in higher interchange fees, is that higher issuer concentration results in more powerful issuers that can put pressure on competing networks to set higher interchange fees with the threat of moving their business to a rival network if they do not. Of course, a final possibility is that the relationship is spurious, and that with the addition of more data points, the relationship will disappear.

It is feasible to test between these different possibilities by looking at how the nature of issuer competition and profitability changed over this period. Interestingly, the period over which issuer concentration increased has been associated with signs of increased competition in credit card issuing (not less). This tends to rule out both the balancing explanation for higher interchange fees, and that shifting revenues to issuers became more profitable for issuers and acquirers jointly. Consistent with this conclusion is the fact that while the market share of the five largest issuers increased over the period, disparities between the largest issuers actually decreased. For instance, the largest issuer, Citigroup, had a market share in 2003 that was virtually the same as it was in 1990 (close to 18\%). In comparison, the second largest issue in 1990 had a market share of just over 5\%. By 2003, the second largest issuer had a market share of over $14 \%$. In fact, replacing the top-five issuer concentration measure with the more robust HHI measure, which is calculated using data for the twenty largest issuers ${ }^{38}$, reveals a quite different picture of what has happened to issuer concentration over this period. As shown in Figure 5, using this measure there is only a weak (at best) positive relationship between issuer concentration and interchange fees. ${ }^{39}$

The possibility that the increased size of the top issuers over the period has increased their negotiating power within the card associations cannot be ruled out with the available data. This could work in tandem with the relatively strong inter-system competition in the U.S. Card associations may have raised interchange fees to keep large issuers from moving their business across to rival networks. This possibility might help explain why the U.S. has seen increasing interchange fees even as other countries have seen declines.40 It is also consistent with the increase in debit card interchange fees in recent years, as the networks increasingly compete to attract large issuers of these instruments to stay on their systems. Moreover, consistent with this explanation, each of the episodes in which interchange fees have jumped up in the U.S has been associated with a battle to keep issuers. In 1990/91 there was a rise in large non-bank issuers that the networks sought to attract; in 1998/99 there was the realignment of Citibank's business to

\footnotetext{
${ }^{37}$ Recall there are two possible ways this can occur - either since issuers and acquirers together are better off shifting revenues to issuers since with higher concentration issuers now compete away less revenue (this makes raising interchange fees more attractive), or since issuers become more powerful within the card association in terms of negotiating their preferred interchange fee (this makes raising interchange fees feasible).

${ }^{38} \mathrm{HHI}$ is defined as the sum of squared market shares of each of the firms (when market shares are expressed as percentages). An HHI of 10,000 represents the case of a monopoly. Markets with an HHI above 1,800 are generally considered concentrated by the Department of Justice in the U.S. Since issuers below the top twenty are ignored (as are other schemes that issue cards), using only the top twenty MasterCard and Visa issuers means that the HHI measure used here will significantly overstate the true level of market concentration in the industry. On the other hand, to the extent that some of the smaller issuers only serve local geographic markets, it may be appropriate to ignore some of these issuers. In any case, replacing the HHI measure with the HHI calculated assuming all smaller card issuers are of equal size does not materially change the result.

${ }^{39}$ A similar result emerges if the HHI of the top twenty issuers is replaced by the difference between the HHI of the top ten issuers less that of the top ten acquirers. This particular definition is used to maximize available data points, although 1990 and 1992-1994 remain missing. The data is again from selected Nilson reports.

${ }^{40}$ Of course, interchange fees have been subject to regulatory limits in some countries, as documented in Section 3.
} 
MasterCard; and from 2003/04 American Express has increasingly been courting existing MasterCard and Visa issuers by offering the equivalent of higher interchange fees. ${ }^{41}$

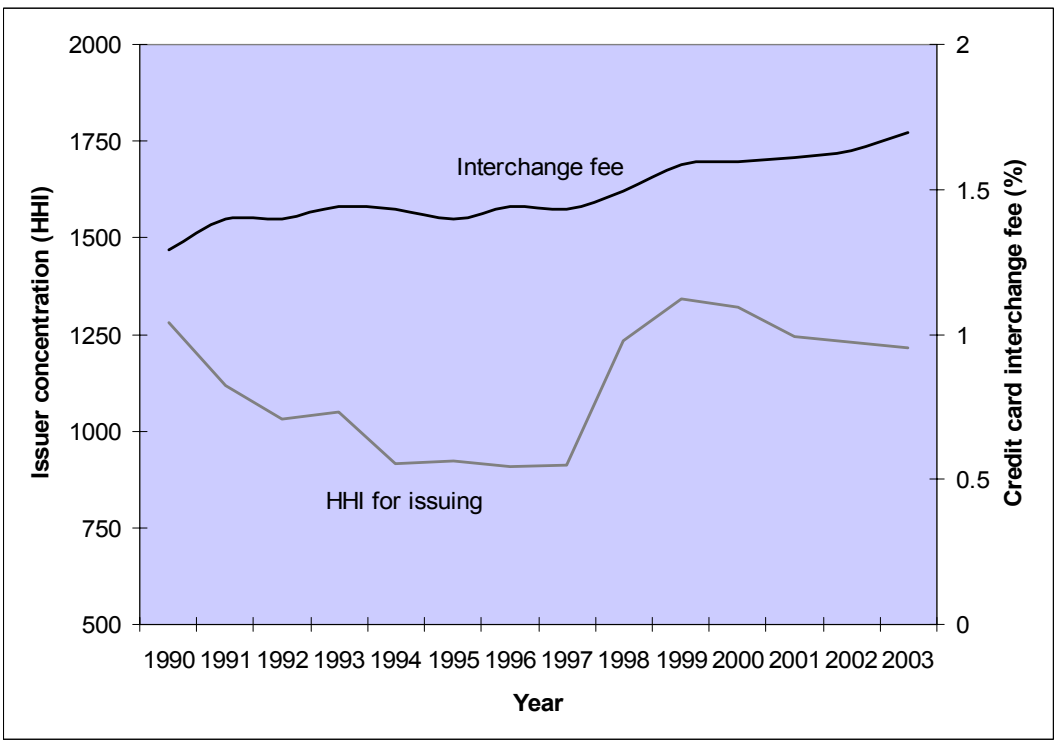

Figure 5: Interchange fees and HHI issuer concentration in the U.S.

Overall, the results suggest that, consistent with the recent theories of interchange fees, interchange fees will be determined by multiple factors, so that to properly explain them will require a multivariate approach. The cross-country data reject the simplistic notion that the level of interchange fees is solely a reflection of the market concentration of issuers. For the U.S., there is evidence of a positive correlation between the market share of the largest issuers and interchange fees over time. However, evidence on issuer competition and a more robust HHI measure of issuer concentration over the same period, suggests that the reason for this positive correlation, if it is real, is not likely due simply to variation in the market power of issuers. Rather, it seems that the increasing ability of large issuers to play one network off against another to raise interchange fees may provide a more fruitful avenue for explaining the finding.

\section{$5 \quad$ Closing remarks}

Interchange fees and related issues in credit and debit card markets have been the focus of considerable attention in recent years. The academic community has begun to address the economics of these markets. Public officials have begun to address the policy implications of developments in these markets. Meanwhile, these markets continue to experience dynamic change as credit, and especially debit, transactions account for an ever-growing share of overall payments.

This paper provides an overview of interchange fee developments and issues in a number of countries. It also presents a preliminary analysis of some possible contributing factors. The

41 For further discussion, see, for example, Evans and Schmalensee (2005a). 
overriding conclusion of the paper is that interchange arrangements vary considerably across countries, and while existing economic theory provides some insight into fee levels and movements, much remains to be explained. A number of complex and interrelated factors, many country-specific, play a role in interchange developments. Researchers and policy authorities alike need richer data sources to more deeply study and examine these markets.

Looking ahead, credit and debit card markets undoubtedly will continue to evolve. If history is any guide, developments in one country may differ markedly from developments in others. The challenge before all interested parties - industry participants, academics, the regulatory community, and central bankers - will be to be in a position to adequately understand these changes.

\section{References}

American Express (2004) Annual Report.

Armstrong, Mark (2004) "Competition in Two-Sided Markets," mimeo, University College, London.

ATM \& Debit News (2002-2005) EFT Data Book.

Bank for International Settlements (1996-2001) Statistics on Payment Systems in the Group of Ten Countries: Figures for 1995-1999. Basle, Switzerland.

Bank for International Settlements (2003) Payment and Settlement Systems in Selected Countries. Basle, Switzerland.

Bank for International Settlements (2002-2005) Statistics on Payment and Settlement Systems in Selected Countries: Figures for 2000-2003. Basle, Switzerland.

Baxter, William (1983) "Bank Interchange of Transactional Paper: Legal Perspectives," Journal of Law and Economics, 26: 541-588.

Caillaud, Bernard and Bruno Jullien (2003) "Chicken \& Egg: Competition Among Intermediation Service Providers," RAND Journal of Economics, 34: 309-328.

Card Industry Directory (2000-2005) Various Issues. Thomson Media. New York, NY.

Chakravorti, Sujit (2003) "Theory of Credit Card Networks: A Survey of the Literature," Review of Network Economics, 2: 50-68.

Castano, Ivan (2005) "Spain to Slash Card Interchange Fees," Cards International, Issue 337, April.

Cruickshank, Don. (2000) Competition in UK Banking: A Report to the Chancellor of the Exchequer. HMSO, Norwich, March.

Dove Consulting (2001) 2001 Study of Consumer Payment Preferences. 
Dove Consulting (2002) Debit Card Survey: Cardholder Fees and Industry Outlook.

Dove Consulting (2004) Debit in Canada: An Overview of the Canadian Debit System and Comparison with the U.S. Model.

European Card Review (2003-2005) European Payment Cards Yearbook: Volume I. Norfolk: United Kingdom.

European Card Review (2003-2005) European Payment Cards Yearbook: Volume II. Norfolk: United Kingdom.

European Central Bank (2000) Payment Systems in the European Union: Addendum Incorporating 1998 Figures. Frankfurt am Main, Germany.

European Central Bank (2001) Payment and Securities Settlement Systems in the European Union. Frankfurt am Main, Germany.

European Central Bank (2004) Payment and Securities Settlement Systems in the European Union: Addendum Incorporating 2002 Figures. Frankfurt am Main, Germany.

European Commission (2001) "Regulation No. 2560/2001 of the European Parliament and of the Council: Cross-Border Payments in the Euro," Official Journal of the European Communities, 344: 13-16.

European Commission (2002) "Commission Decision Relating to a Proceeding under Article 81 of the EC Treaty and Article 53 of the EEA Agreement," Case No. COMP/29.373-Visa International-Multilateral Interchange Fee, 318: 17-36.

Euromonitor (2004) Financial Cards in Mexico.

Evans, David (2003a) "The Antitrust Economics of Multi-Sided Platform Markets," Yale Journal on Regulation, 20: 325-82.

Evans, David (2003b) "Some Empirical Aspects of Multi-sided Platform Industries," Review of Network Economics, 2: 1-20.

Evans, David and Richard Schmalensee (2005a) Paying with Plastic: The Digital Revolution in Buying and Borrowing. Second Edition. MIT Press: Cambridge, MA.

Evans, David and Richard Schmalensee (2005b) "The Economics of Interchange Fees and Their Regulation: An Overview," paper presented at the Conference of Interchange Fees in Credit and Debit Card Industries: What Role for Public Authorities? Kansas City Federal Reserve Bank, Santa Fe New Mexico, May 4-6.

Executives Meeting of East Asia-Pacific Central Banks and Monetary Authorities (2002) Payment Systems in EMEAP Economies, EMEAP Working Group on Payment and Settlement Systems. 
Federal Reserve System (2002) 2001 Retail Payments Research Project: A Snapshot of the U.S. Payments Landscape.

Federal Reserve System (2004) 2004 Federal Reserve Payments Study: Analysis of Noncash Payments Trends in the United States: 2000-2003.

Frankel, Alan S. (1998) "Monopoly and Competition in the Supply and Exchange of Money," Antitrust Law Journal, 66: 313-361.

Gans, Joshua and Stephen King (2003) "The Neutrality of Interchange Fees in Payment Systems," Topics in Economic Analysis \& Policy, 3.

Guthrie, Graeme and Julian Wright (2003) “Competing Payment Schemes," Working Paper No. 245, Department of Economics, University of Auckland.

Guthrie, Graeme and Julian Wright (2005) "Competing Payment Schemes," mimeo, Department of Economics, National University of Singapore.

Hayashi, Fumiko (2004) "A Puzzle of Card Payment Pricing: Why Are Merchants Still Accepting Card Payments?" Working Paper No. WP04-02, Federal Reserve Bank of Kansas City Payments System Research 2004.

Hayashi, Fumiko, Richard Sullivan, and Stuart E. Weiner (2003) A Guide to the ATM and Debit Card Industry. Federal Reserve Bank of Kansas City: Kansas City.

Hunt, Robert (2003) "An Introduction to the Economics of Payment Card Networks," Review of Network Economics, 2: 80-96.

IMA Market Development AB (2000) Study Regarding the Effects of the Abolition of the Nondiscrimination Rule in Sweden. Commissioned by European Commission Competition Directorate General.

ITM Research for Competition DG (2000) The Abolition of the No-discrimination Rule. Commissioned by the European Commission Competition Directorate General.

Katz, Michael (2001) Reform of Credit Card Schemes in Australia II: Commissioned Report RBA Public Document. August.

Lett, Vilstrup \& Partners (2005) The Danish Act on Certain Payment Instruments. http://www.legal500.com/devs/denmark/tm/dktm 001.htm

Netherlands Competition Authority (2003) Financial Sector Monitor 2003: Views of NMa on Competition in the Financial Sector. The Hague: The Netherlands.

Netherlands Competition Authority (2004a) Interpay: Case No. 2910 Decision. April 21.

Netherlands Competition Authority (2004b) Decision No. 2910-700, Case: Interpay. April 28. 
Netherlands Competition Authority (2005) "NMa Fines Interpay and Banks for Infringement of Competition Act.” Press Release, April 29, 2005.

Nilson Report (1991-2005) various issues. HSN Consultants Inc. Oxnard, CA.

Reserve Bank of Australia (1999-2004) Payments System Board Annual Reports, Sydney.

Reserve Bank of Australia (2001) Reform of Credit Card Schemes in Australia, I: A Consultation Document. December. Sydney.

Reserve Bank of Australia (2002) Reform of Credit Card Schemes in Australia, IV: Final Reforms and Regulation Impact Statement. August. Sydney.

Reserve Bank of Australia (2005) Reform of the EFTPOS and Visa Debit Systems in Australia: A Consultation Document. February, Sydney.

Reserve Bank of Australia and Australian Competition and Consumer Commission (2000) Debit and Credit Card Schemes in Australia: A Study of Interchange Fees and Access. October. Sydney.

Rochet, Jean-Charles (2003) "The Theory of Interchange Fees: A Synthesis of Recent Contributions," Review of Network Economics, 2: 97-124.

Rochet, Jean-Charles and Jean Tirole (2002) "Cooperation among Competitors: Some Economics of Payment Card Associations," RAND Journal of Economics, 33: 549-570.

Rochet, Jean-Charles and Jean Tirole (2003a) "Platform Competition in Two-Sided Markets," Journal of the European Economics Association, 1: 990-1029.

Rochet, Jean-Charles and Jean Tirole (2003b) "An Economic Analysis of the Determination of Interchange Fees in Payment Card Systems," Review of Network Economics, 2: 69-79.

Rochet, Jean-Charles and Jean Tirole (2004a) "Defining Two-Sided Markets," mimeo, IDEI, Toulouse, France, January.

Rochet, Jean-Charles and Jean Tirole (2004b) "Two-Sided Markets: An Overview," mimeo, IDEI, Toulouse, France, March.

Schmalensee, Richard (2002) "Payment Systems and Interchange Fees," Journal of Industrial Economics, 50: 103-122.

Wellink Report (2002) Tariff Structure and Infrastructures in Dutch Retail Payments. De Nederlandsche Bank NV.

World Bank (2003) Payments and Securities Clearance and Settlement Systems in Mexico. Durango, Mexico.

Wright, Julian (2004) "Determinants of Optimal Interchange Fees in Payment Systems," Journal of Industrial Economics, 52: 1-26. 